\title{
The Legal Services Corporation: Curtailing Political Interference*
}

The 92d Congress is now considering, for the second time, legislation that would establish an independent National Legal Services Corporation to administer the nationwide legal services program presently operated by the Office of Economic Opportunity (OEO) .1 In its first session, the Congress passed this legislation, but it was vetoed by the

* This Note draws to a considerable degree on unpublished materials such as letters, telegrams, reports, memoranda, special investigations, evaluations and notes of the authors. All such materials are on file with the Yale Law Journal.

1. H.R. 12350, 92d Cong., 2d Sess. (1972); S. 3191, 92d Cong., 2d Sess. (1972). The provisions of these bills with respect to legal services are nearly identical with those of S. 2007, the legislation passed by the current Congress in its first session. S. 2007, 92d Cong., lst Sess. (1971). Each of these bills contains a section (S 21 of H.R. 12350 and $\$ 17$ of S. 3191) amending the Economic Opportunity Act of 1964 to add a new Tide authorizing the creation of a National Legal Services Corporation. Sce Economic Opportunity Act of 1961, 42 U.S.C. § 2701 et seq. (1970). Sections 1001 to 1016 of H.R. 123j0 would create a new Title X, while $\$ \$ 901$ to 916 of $S .3191$ would include substantially identical provisions in a new Title IX. H.R. 12350 was approved by the House of Rep. resentatives on February 16, 1972, and, as of this writing, S. 3191 has not yet been reported out of the Senate Committee on Labor and Public W'clfare. Hercinafter. H.R. 12350 will be cited as "The Bill," with the understanding that unless othervise specified S. 3191 contains an equivalent provision. The Bill contains a number of other amendments to the Economic Opportunity Act of 1964, similar to those in S. 2007, including a provision to authorize appropriations to the Office of Economic Opportunity for twio more years. See S. $2007 \$ \$ 2$, 3; The Bill \$\$ 2, 3. Like S. 2007, both vould repeal the existing portions of the law dealing with the OEO Iegal services program, 42 U.S.C. \$ 2809(a)(3) (1970). See S. 2007 \$ 1001(b) (2); The Bill § 1016(d). Unlike S. 2007, hovever, these bills do not have a provision for a Comprehensive Child Development program and would authorize, instead, an increase in the cxisting Head Start program. See 42 U.S.C. $\$ 2809$ (a)(1) (1970).

Passage of S. 2007 in the first session followed a prolonged period of legislative wrangling, much of it focusing on the legal services provision. The first major legislative proposal was submitted by a bi-partisan coalition of Congressmen led by Representatives Lloyd Meeds and William Steiger and Senators Mondale and Javits, on March 18, 1971. See H.R. 6360, 92d Cong., Ist Sess. (1971). The Administration submitted its ovin bill on-May 5,1971 , accompanied by a Presidential Message on the future of legal services. See H.R. 8163, 92d Cong., lst Sess. (1971); S. 1769, 92d Cong., Ist Sess. (1971). See also President Richard Nixon, Message to Congress, 7 Whry. CoMr. Pres. Doc. 726 (May j, 1971); Press Conference of Frank Carlucci, Director of the Office of Economic Opportunity, May 5, 1971. The issue which drew most public attention and backstage dispute was the structure and method of selection of the board of directors. The bi-partisan bill would have created a board of nineteen members, only five of them appointed by the President. The Administration bill would provide for an eleven-member board, with the President appointing all of them. But the bi-partisan coalition also objected strongly to a number of other provisions of the Administration proposal which they regarded as restrictive. See note 159 infra. The two congressional committees-the House Committee on Education and Labor and Senate Commitice on Labor and Public Welfare -produced bills which they frankly regarded as a "compromise." H.R. REs. No. 92-471, 92d Cong., lst Sess. at 32 (1971) [hereinafter cited as House Reiorr]; S. REr. No. 92.331, 92d Cong., 1st Sess. (1971) [hereinafter cited as Sesate Reiort]. Each House of Congress substantially approved the bill reported out by its respective committec, so that further compromise was necessary in conference to resolve differences between the House and 
President on December 9, 1971.2 The legislation now under considerntion, like that previously approved, would transfer authority for the program to an independent board of directors, appointed by the President according to specified procedures. ${ }^{3}$ Throughout, the preeminent purpose of the legislation has been to insulate the program from po. litical interference, or, as the bill puts it, "extraneous interference and control." 4

This Note will argue that the establishment of an independent Corporation is only a partial solution to the problem of interference. A major contributing cause of the program's current vulnerability to such interference has been a failure of policysetting and responsiveness. ${ }^{5}$ It has been a dual failure: there has been no clear articulation of policies for projects and personnel to follow; nor has there been a solution to the problem of defining the proper roles of various constituencies in determining policies. A similar failure in the new Corporation would continue to be an important factor in causing vulnerability. In Part I, this Note attempts to show how failures of policysetting and responsiveness contributed in specific instances to the vulnerability of individual legal services projects. Part II sets forth a normative analysis of responsiveness that suggests particular criteria by which control over

Senate versions. Compare H.R. 10351, 92d Cong., Ist Sess. (1971), with S. 2007, 92d Cong., lst Sess. (1971). As embodied in the conference report and approved by Congress, S, 2007 would have created a seventeen-member board, appointed by the President with the consent of the Senate, with substantial participation in the selection process by various professional and client groups through the submission of lists of nominees. Ste note 182 infra. See Joint Explanatory Statement of the Committee of Conference, 117 CoNG. REC. 19835 (daily ed. Nov. 30, 1971).

2. The major reason given for the President's veto was his opposition to Title V in S. 2007 authorizing the expenditure of more than $\$ 2$ billion on Child Development Programs. Aid to such programs, the President contended, would involve excessive costs and uncertain benefits. In his veto statement, however, the President sharply criticiecd Title IX, the provisions creating a National Legal Services Corporation, noting that it differed "crucially from the proposal originally put forth by this Administration." The legislation had lost "the quintessential principle of accountability" and "the door has been left wide open to those abuses which have cost one anti-poverty program after another its public enthusiasm and public support." Specifically, the President complaincd of restrictions on the President's appointment of board members as "an affront to the principle of accountability to the American People as a whole." He concluded: "It would be better to have no legal services corporation than one so irresponsibly structured." The President's Message to the Senate Returning S. 2007 Without His Approval, 7 WkLY. Comp. Pres. Doc. 1634 (Dec. 9, 1971).

3. The Bill $\$ 1004$ (a). See note 132 infra.

4. The Bill \$1001(6). See also Report of the President's Commitree on Executive Organization app. 6 (1970); The President's Message to Congress Proposing Establishment of the Independent Corporation, 7 WKLY. Comp. Pres. Doc. 727 (May 5, 1971) ("[1]f Wc are to preserve the strength of the program, we must make it immune to political pressures and make it a permanent part of our system of justice."). The House Report and Senate Report have identical language in many places on the need for independence. See, e.g., House REPORT, supra note 1, at 26.33, and SENATE REPORT, supra note 1, at 29.

5. See pp. 233-35 infra. 
the program should be apportioned among competing constituencies. ${ }^{\circ}$ In Part III, the Note applies this analysis of policysetting and the allocation of political control to three key policy issues facing the program: the structure of institutions with responsibility for guidance and supervision; the eligibility of clients; and the range and mix of services to be provided.

It should be emphasized that neither adequate policysetting nor a well-defined allocation of control within the program will eliminate the motivations for or provide full protection from political attacks. Those who feel their interests jeopardized or damaged by a legal services project are bound to fight back, and it is almost inevitable that a program of advocacy designed to further the interests of the poor will impinge on the vital interests of other groups. The measures suggested here would reduce the program's vulnerability to such attacks by strengthening its defenses and clearly distinguishing between proper and improper intervention. In addition, they would enhance the program's ability to reach its goals as established by the legislation and defined by the Corporation.

\section{Policysetting, Responsiveness and Political Interference}

\section{A. Definitions of Policysetting and Responsiveness}

Policysetting may be defined as a concept of management consisting of five elements: first, the definition of goals and priorities; second, the articulation of those goals and priorities through coherent standards and guidelines; third, the reporting of performance data so that the program may be evaluated in terms of its stated goals and priorities; fourth, enforcement of standards and guidelines where projects do not comply voluntarily; and fifth, the precise delineation of responsibility for each of these tasks. ${ }^{7}$ Responsiveness is the sensitivity of an institu-

6. Even if the normative analysis of responsiveness advanced here provokes disagree: ment, it is vital that some method of allocating political control be formulated and officially adopted in order to create the criteria by which the legitimacy of claims by constituencies may be judged. Political interference must be defined and identified on the basis of some general distinction between proper and improper claims on the program. No such normative analysis has ever been attempted, eren in rough form, which accounts for the difficulty the program has had in defining "political interterence."

7. Policysetting, it should be noted, is given a definition here different from that in ordinary usage. Normally, the concept might not include clements of cnforcement, review of performance data, or delineation of responsibility. Under the definition adopted here, it is possible that some of these elements may be accomplished and others not, resulting in varying degrees of policysetting. For cxample, a program might fully define and articulate policies but fail to enforce them. This vould be, nonetheless, a failure of policysetting. 
tion to the interests of various constituencies. ${ }^{8}$ Responsiveness may be manifested in particular substantive policies, but the most important step in achieving responsiveness occurs in structuring the governing boards of the legal services program, both at the local and national levels. The critical question is what amount and type of representation should be given to the various competing constituencies. ${ }^{0}$

In discussing the legal services program, it is useful to distinguish four constituencies-the professional community (the bar), the community at large, the client community and the legal services attorneys. ${ }^{10}$ By determining in advance the extent to which a legal services program should be responsive to these constituencies, one can distinguish between legitimate and illegitimate claims and demands as they arise.11

8. The concept of responsiveness may be analyzed normatively or empirically. A normative analysis of responsiveness tells how control of a particular institution should be allocated to its constituencies. An empirical analysis tells how control actually is allocated. A failure of responsiveness occurs when a constituency is allocated more or less control than is warranted by the criteria of a normative analysis. This may occur through a deficient analysis of the way in which control should be allocated, or by default. In the legal services program, the failure has taken both forms. In alleging its failure in the former sense, this Note uses the criteria suggested by the normative analysis pre. sented in the next section. See pp. 266-71 infra.

9. Responsiveness to a particular constituency might be examined in terms of cither outcome or process. The two approaches, however, are closely linked. Indced, one of the key indicators of the quality of representation-its effectiveness-is its product, the policy outcome.

10. These constituencies may be defined in such a way that they are non-overlapping interest groups. The client community consists of individuals who are eligible for legal services, and the legal services attorneys are those lawyers employed full-time by local projects. The professional community comprises all attorneys who are members of the bar, with the exception of legal services attorneys. All individuals who are not members of any one of the foregoing constituencies are members of the community at large. Such definitions, incvitably, are somewhat artificial, since an individual may regard himself as a member of more than one constituency, and different members of one constituency may have significantly different interests. In some cases, there may be questions as to which constituency a particular member of the board represents-a lawyer, for ex. ample, may claim to represent the poor while voting with the professional community's interests. See note 45 infra. As a practical matter, the allegiance of some board members (and the actual allocation of power within the board as a whole) may be assessed only by scrutinizing votes and policy outcomes over a significant period. But this method of making constituency classifications, though more accurate, is simply unworkable. Hence this Note makes the assumption that classification of individuals by their status is a reasonable way of reflecting their interests. The experience in the program to date sccuns to suggest that this assumption is accurate. Classifications are therefore made here on the basis of status, but exceptions are noted where they are of potential importance.

For the purpose of defining the client community, the meaning of "eligibility" is identical to the standard of eligibility adopted by the program to deterinine which individuals are qualified to receive service. To be a member of the client community, an individual need not be an actual recipient; he need only be a potential recipient, or, in other words, within the outer financial parameters of cligibility. The legislation supports the adoption of such a status classification. It stipulates, for example, that at least one third of project governing board members must be "members of the clicnt community." The Bill $\S 1006(b)(6)$. "Member of the client community" is defined als "any person unable to obtain private legal counsel because of inadequate financitil means." The Bill \& 1012(4).

11. The legitimacy of a claim, as discussed here, goes not to the merit of the particular demand, but rather to the constituency making the claim and the issue as to 
Thus, comparing the two concepts, policysetting applies to the internal decisionmaking process, while responsiveness pertains to the allocation of political control of the program among its various constituencies. As applied to other agencies, both concepts might be subsumed under the term "accountability." Breaking that term into its two components affords greater clarity, however, and allows adjustment for the "independence" of the Corporation. ${ }^{12}$

\section{B. The Present Program and Statute}

Legal services are provided under the present program by a network of local projects which receive yearly grants from the Office of Legal Services (OLS) in OEO. The bulk of the OLS budget of $\$ 60$ million in fiscal year 1970 was devoted to providing such grants to some 293 projects, with approximately 2,200 full-time lawyers serving 500,000

which the claim is made. See pp. 268-71, 279-81 infra. The merit of particular demands, e.g., whether a particular type of suit should be entertained, is left to political resolution by the various legal services constituencies whose participation is discussed below. The legitimacy of a claim is a notion introduced solely to distinguish political interference (illegitimate) from political intervention (legitimate). Legitimacy, then, does not determine a particular outcome on any policy issue, but only the inputs which should be taken into account.

12. The independence or autonomy of the National Legal Services Corporation nees. sitates the concepts of policysetting and responsiveness employed in this analysis. Accountability normally includes the notion of an agency justifying its actions-explaining past policies and outlining plans for the future-to Congress or the President. The mechanism through which accountability usually operates is the budget process: requests for spending authority made to the president (through the Office of Mfanagement and Budget) and to Congress (through the appropriate committee for authorization appropriations) provide the context in which performance is reviewed and policy options presented. This process would continue to be followed, in form, by the National Legal Services Corporation. But the President would be prohibited from attempting to control the Corporation's policy in any way. The Bill $\$ 1013$. And, among the fimits to its orersight of the program, Congress would stipulate that the Corporation cannot be expected to provide information which would abridge "the necessity of maintaining the confidentiality required by the best standards of the legal profession." Id. \$ $1010(a, b)$. Implicit in the bill and frequently stated throughout the legislative history, is the notion that the kind of accountability required of other agencies could not be demanded of the Legal Services Corporation. If it were truly independent, the Corporation could not be called upon to account for its decisions with respect to a particular case or project, or even many of its more general policy decisions involving judgments of priorities or eli: gibility. The closest analogy would be the position of the Corporation for Public Broadcasting (CPB). There, officials have contended that First Amendment rights of grantees would be jeopardized by congressional inquiry into programming decisions, and have argued that Congress is entitled to only "rough breakdowns in catcgorics of expendiure." Interview with John Macy, Director, Corporation for Public Broadcasting, in Washington, D.C., Oct. 15, 1971. They have resisted the idea that the CPB should be accountable to the Congress, or to the President, in the same manner as other federal agencies. They have acknowledged, nonetheless, that it must be responsive in some sense to certain constituencies such as local affiliates, subscribers and, ultimately, its listeners. With respect to the Legal Services Corporation, a notion of accountability different from the one normally applied to federal agencies would seem equally desirable. The right to protection of the attorney-client relationship and the explicit congressional intent unat the Corporation be independent would seem to have the same foree as analogous considerations affecting the CPB. 
clients. The OLS also funded various experimental projects, research activities and volunteer programs. ${ }^{13}$

The federal program began as an experimental stepchild of the Community Action program. ${ }^{14}$ It was not given the status of a separate branch of OEO until 1969, when President Nixon reorganized the antipoverty program. At the local level, about ninety per cent of the projects are still delegate grantees of Community Action Agencies (CAA's), and their funds flow through these non-profit antipoverty organizations. At a minimum, delegate status means review by the CAA of all applications for grants, as well as performance of certain bookkeeping and management tasks. ${ }^{15}$

13. Office of Legal Services Research and Development Plan for fiscal ycar 1971, April 1970. The program has thus more than doubled in size since fiscal year 1966, when $\$ 26$ million was allocated to fund 157 projects with approximately 1,000 lawyers. Ill.

14. The first legislative authorization for the creation of the Office of Economic Opportunity, and the so-called War on Poverty, was the Economic Opportunity Act of 1964, Act of Aug. 20, 1964, Pub. L. No. 88-452, 78 Stat. 508 (codified at 42 U.S.C. \$S 2701-2994d (1970)). Legal Services was initiated by OEO officials under the very gencril authority provided by Title II of that legislation, relating to the creation and finding of the Community Action Program. Not until passage of the Economic Opportunity Amendments of 1966 was Legal Services specifically authorized under \& 222(a) of the Economic Opportunity Act of 1964. See Act of Nov. 8, 1966, Pub. L. No. 89.794, \$222(a), 80 Stat. 1451 (codified at 42 U.S.C. $\$ 2809$ (1970)). The authorization, consisting of onc sentence, mandated the Director of OEO to provide "legal advice and legal representa. tion" to persons eligible for assistance from OEO "when they are unable to atford the services of a private attorncy ... to further the cause of justice among persons living in poverty." The Director was required to "establish procedures to assure that the principal local bar associations in the area to be served by any proposed program of legal advice and representation are afforded an adequate opportunity to revicw the proposed program and to submit comments and recommendations thereon before stuch program is approved or funded."

15. The relationship between community action agencies and legal services projects has been subject to increasing dispute as the projects have gained confidence and pressed for autonomy. Originally, almost all legal services projects received their funds as delegates of CAA's. The founders of the program, officials of the OEO Community Action Program, were inspired largely by an article written by Edgar and Jcan Calin on neighborhood law offices. See Cahn \& Cahn, The War on Poverty: A Civilian Per. spective, 73 YALE L.J. 1317 (1964). They chose to ignore the article's warning that legal services should not be subordinated to the overall strategy (the so-called "military perspective") of the war on poverty. Throughout the history of OEO legal services, one of the most fundamental unresolved issues has been whether the program should serve a community action strategy for fighting poverty-a strategy planned and directed by the local CAA for fighting poverty community-wide, mobilizing all the resources and services available to accomplish its ends. The founders of Community Action saw legal services as one weapon in the arsenal of the war against poverty, a tool or tactic to be maneuvered and manipulated or "traded off" in response to political or budgetary pres . sures in the "larger picture." See R. Blumenthal, The Bureaucracy: Antipoverty and the Community Action Program, in American Political Institutions Policy 128.80 (A. Sindler ed. 1969). But legal services attorneys balked at subservience to any higher stratcgy, at any level, and pressed for independence from Community Action. Until 1969, the Director of OLS was a subordinate of the Assistant Director of OEO for the Community Action Program. In reorganizing OEO, President Nixon established legal services as at separate entity on the organization chart and gave the Director of OLS the additional title of Associate Director of OEO for Legal Services so that he would henceforth report directly to the Director of OEO. See Statement by the President Outlining Changes in the Office of Economic Opportunity's Organization, Structure and Operating Procedures, 5 WKLY. Comp. Pres. Doc. 1132, 1135 (Aug. 11, 1969) ("The sluggishness of many insti. 
According to the current statute, the goal of the legal services program is "to further the cause of justice among persons living in poverty by mobilizing the assistance of lawyers and legal institutions and by providing legal advice, legal representation, legal counseling, education in legal matters and other appropriate legal services." ${ }^{10}$ The only requirements of the statute are that: (l) services must be of a high professional quality and must maintain the attorney-client relationship; (2) the Director of OEO must make arrangements for local and state bar associations to be consulted prior to funding or refunding projects; (3) neither funds nor personnel may be used for representation of any person indicted (or proceeded against by information) for commission of a crime. ${ }^{17}$ In addition, the program is subject to requirements in other parts of the Economic Opportunity Act which pertain to all OEO programs, particularly provisions which give state governors a quali-

tutions-at all levels of society-in responding to the needs of individual citizens, is one of the central problems of our time."). See also The President's Address to the Nation on Dontestic Programs, 5 WrLy. Cosr. Pres. Doc. 1103, 1108 (Aug. 8, 1969). Administrative independence at the national level, however, has not protected legal services projects from interference by local CAA's. As a number of observers commented, "attempted domination of lawyers by Community Action Agencies and officials at various governmental levels has interfered significantly with the effectiveness of the program, demoralized many of the bright young attorneys attracted to the program, delajed the making of crucial decisions and impeded the necessary growth of the Icgal services program." Memorandum from Representatives of the ABA and NLADA to the Secretary of Health, Education, and Welfare, Robert Finch, Feb. 6, 1969, re OEO Legal Services. quoted in Hannon, Legal Services and the Local Bars: How Strong is the Bond? 6 CALIF. WEST. L. REV. 46, 47 (1969). This is confirmed by many present oLs officials and former directors. Interview with Terry Lenzner, former Director of OLS, in Washington. D.C., Aug. 22, 1971; interview with E. Clinton Bamberger, former Director of OLS, in Washington, D.C., Sept. 2, 1971; interview with Fred Speaker, former Director of OLS, in Washington, D.C., Aug. 19, 1971; interview with Earl Johnson, former Director of OLS, in Washington, D.C., Sept. 15, 1971; interview with Dan Bradley, Regional Director of OLS, Southeast Region, in Washington, D.C., Sept. 16, 1971. Sec also Hannon. Legal Services and the Community Action Program: Oil and Water in the War on Poverty, 28 Legal Aid Briefcase 5 (1969).

16. This authorization in its present form was contained in the Economic Opportunity Amendments of 1967, Act of Dec. 23, 1967, Pub. L. No. 90.222, 81 Stat. 672 (codified at 42 U.S.C. $\$ 2809$ (1970)). The provision claborated somewhat on the enumemtion of services to be provided, but retained approximately the same statement of goals as the Economic Opportunity Amendments of 1966, Act of Nov. 8, 1966, Pub. I. No. 89-794, 80 Stat. 1472 (codified at 42 U.S.C. $\$ 2809$ (1970)). See note 14 supra. In addition, it included two significant requirements. One related to the attorney-client relationship: "Projects involving legal advice and representation shall be carried on in a way that assures maintenance of a lawyer-client relationship consistent with the best standards of the legal profession." 42 U.S.C. $\$ 2809$ (a)(3) (1970). The sccond was the restriction on repre. sentation in criminal cases: "No funds or personnel made available for such program (whether conducted pursuant to this section or any other section in this part) shall be utilized for the defense of any person indicted (or proceeded against by intormation) for the commission of a crime, except in extraordinary circumstances where, after consul. tation with the court having jurisdiction, the Director has determined that adequate legal assistance will not be available for an indigent defendant unless such services are made available." Id.

17. Id. The provisions of the Economic Opportunity Act of 1964 and subsequent amendments pertaining only to legal services have been codified at 42 US.C. $\$ 2809(a)(3)$ (1970). 
fied power to veto grants to legal services projects in their states ${ }^{18}$ and which require projects to furnish twenty per cent of local costs. ${ }^{10}$

\section{The Failure of Policysetting: Legal Services Guidelines}

The failure of policysetting in legal services has been evident in the vagueness of policy guidelines and standards, their silence on many issues, and the uneven nature of their enforcement. The first formal Legal Services Guidelines were issued in 1965, and were acknowledged to be vague and unspecific on a number of issues. ${ }^{20}$ Though there were subsequent changes in OEO policies on legal services, some discretionary and others mandated by Congress, the Guidelines were never again revised formally. Officials occasionally issued new interpretations of policies through OEO Instructions, or Community Action Memo. randa. ${ }^{21}$ Most often, however, these policy statements were expressed

18. 42 U.S.C. $\$ 2834$ (1970). A plan describing any project funded by OEO must be submitted to the governor within the state for which it has been proposed. The governor is given thirty days within which to consider it. If the governor vetoes the project, the Director may implement the project only if he reconsiders and finds it "fully consistent with the provisions and in furtherance of the purposes" of the antipoverty progratl. Originally, the Economic Opportunity Act of 1964 did not contain this provision for overriding a governor's veto by a Director. It was added by the Economic Opportunity Amendments of 1967. Act of Dec. 23, 1967, Pub. L. No. 90-222, \$ 242, 81 Stat. 706 (codificd at 42 U.S.C. $\$ 2834(1970)$ ). See note 16 supra.

19. 42 U.S.C. $\$ 2812$ (c) (1970). Under this provision, financial assistance to a $\mathrm{C}_{4} \mathrm{l} .1$ or other agency may not exceed eighty per cent of the costs of a project. However, the director may waive this requirement "if he determines, in accordance with regulations establishing objective criteria, that such action is required in furtherance of the purposes" of the antipoverty program. "Non-federal contributions may be in cash or in kind, fairly cvaluated, including but not limited to plant, equipment or services." This pro. vision was added by the Economic Opportunity Amendments of 1967. Act of Dec. 23. 1967, Pub. L. No. 90-222, § 225(c), 81 Stat. 702 (codified at 42 U.S.C. \$ 2812 (1970)). Sec note 15 supra.

20. Office of Economic Opportunity, Guidelines For Legal Services Programs (1967) [hereinafter cited as Guidelines]. Interview with Francis Duggan, Director of Opcrations, OLS, in Washington, D.C., Aug. 21, 1971. In response to many inquirics, OLS officials said that further written directives would be forthcoming, but in fact few were isstucd. Five "overall objectives" are stated in the Guidelines: to provide funds implementing local programs of advice and advocacy for the poor; to accumulate empirical information with respect to experiment and innovation; to sponsor education and research in areas of procedural and substantive law affecting the poor; to acquaint the bar with its essential role in combatting poverty; to teach the poor and those who work with them to recognize problems which can be resolved through law. Guidelines at 1 .

21. The legal force of the Guidelines Instructions and Memoranda was never fully defined. The Guidelines and many of the most important Instructions and Memoranda were not promulgated as official federal regulations in the Code of Federal Regulations under the Administrative Procedure Act, 5 U.S.C. $\$ 553$ (1970) (unless otherwise noted, the Instructions and Memoranda discussed in this Note have not been officiatly promul. gated); nor has any procedure ever set forth the process of formulation and publication. Nonetheless, OEO officials considered them in some sense binding on grantces, In case of violation, the sanctions were primarily suspension or termination of the grant, or denial of refunding. These sanctions were usually not invoked, however, unless the grantee refused to take disciplinary action against an offending employec or to correct abuses and avoid repetition of the violation. 
informally and ad hoc-in letters to individual programs, conditions on particular contracts and in speeches, articles and working memoranda. ${ }^{22}$ During the program's first four years, evaluation of projects was sporadic and followed no uniform criteria. A systematic evaluation effort was commissioned in 1970 under Director Terry Lenzner, but the criteria and processes employed by the two major evaluation contractors differed, and were substantially unrelated to the Guidelines.2s

The lack of policysetting has been particularly significant with respect to three major issues: (1) the duties and structure of institutions responsible for guidance and supervision; (2) the eligibility for services, and (3) the range of permissible services and priorities among them.

Local governing boards have been the institutions principally responsible for guidance and supervision. Yet the OLS never specified the division of responsibility between the local boards and the OLS itself, or their relationship to CAA's, state and local bar associations, and their own attorneys. The Guidelines stipulated only that there be

22. The two principal means of policy communication to individual legal services grantees have been the Evaluation Letter and the Special Condition. The Evaluation Letter was a summary of criticisms and suggestions made by an outside cvaluator team, sometimes including legal services officials, which was sent to the project two weeks to six months after the evaluation was received by OLS. It was signed by a Regional Director of OLS or, more commonly after 1970, by the Deputy Director of OLS or by the Director of Planning, Technical Assistance and Evaluation in the Office of Legal Services. Often, these letters included the threat of denial of refunding if the project failed to follow the evaluation's recommendations. But usually, even in cases of projects rated poor, the possibility of sanctions was stated more obliquely. Sec, e.g., Letter from Winston R. Webster, Director, Office of Planning, Technical Assistance and Evaluation, OLS, to George Wall, Jr., President of the Board of Directors, Delta Legal Aid, Tallulah, La., Aug. 4, 1971: "Compliance with the recommendations of this craluation, and in particular with the special conditions attached to the grant, is extremely important and must become the basis for a major renewal and strengthening of cffort by the Delia Legal Aid Society." See note 57 infra. Special conditions could relate to any issuc, and take any form. Often they were communicated to grantees in the craluation lettcr, sometimes when the project was well into its program jear.

23. Two companies, Auerbach Associates Inc., and John D. Kettelle Corporation, were commissioned in 1970 to perform evaluations individually of all existing legal services projects. Their reports, which are often cited and quoted in this Note, were the only formal evaluations ever performed on many projects. Both companies used teams of evaluators, consisting generally of a legal services official, a lawyer from outside the program, a representative of the client community, and a member of the company's staff. Each member of the team did separate interviews, recorded the results on a standard form, and gave their work product to the Kettelle or Auerbach staff member, who analyzed the results and wrote the report. Neither company drew directly on goals stated by the Guidelines. See note 20 supra. Though each company formulated a standard form for use by its evaluators, the two scts of forms differed in significant respects. Auerbach, for example, divided program activities into major areas-law reform, individual case work, community education, economic development, and community rep: resentation-whereas Kettelle did not. Often the companics covered the same general areas-relations with the CAA or bar association, for example-but emplojed different questions on the standard form. The reports were organized differently and often written in different styles, the Auerbach documents tending to be longer, more detailed, and more penetrating. 
an "autonomous policymaking board." 24 In dealing with bar associa: tions, the Guidelines said that legal services programs should "main. tain continuing cooperation"25 and attempt to "coordinate"20 their activities, in addition to submitting to the bar copies of applications for funding or refunding. As to CAA's, the Guidelines noted that "ordinarily" the projects would be a "component" of the CAA's, "opernting within" them. ${ }^{27}$ But the Guidelines also required that each project should "determine its own policy"-insuring, for example, the "independence of professional legal judgments" from policies of the local CAA. ${ }^{28}$ No further instructions or guidelines were issued on the questions of how much independence from the CAA was to be afforded, or what conditions would justify direct funding of a legal services project instead of funding as a delegate agency. ${ }^{20}$

With respect to eligibility, the Guidelines required projects to "describe the standard by which the eligibility of clients will be determined." 30 This "standard" was reviewed by the OLS prior to funding. But OLS did not specify which body or individual at the local level should have responsibility for proposing and revising such standards. Nor did it formulate criteria by which the acceptability of the stand. ards would be determined. ${ }^{31}$ OLS maintained that the general OEO standard on poverty income levels did not apply to the program, and

24. Guidelines, supra note 20 , at 4 .

25. OEO Instruction No. 6140-1, June 13, 1969, 45 C.F.R. $\$ 1061.2-1$ (1971). By this instruction, the bar associations are given twenty days in which to revicw a proposal submitted to them, and forward "any comments or recommendations" to OEO.

26. Guidelines, supra note 20 , at 1 .

27. Guidelines, supra note 20 , at 2,3 .

28. Guidelines, supra note 20 , at 3 .

29. A "special appeals procedure" was set forth in Community Action Mcmorandum No. 9-A, to be used by a "local agency, public or private, which desires to undertake one or more components of a community action program but has found after first applying to the CAA serving the community that it is impossible or infeasible to com. bine its efforts with those of the CAA." Community Action Memorandum No. 9.A, pt. $B(3)$, Feb. 21, 1967, re Revised policy on funding of independent community action programs, appeals procedure, and neighborhood based CAA's. It provided that an agency "applying under the appeals procedure must submit a letter," along with its application, "which explains why the applicant believes it impossible or infeasible to combine its efforts with those of the CAA." Id. $\mathrm{p}_{\mathrm{t}}$. B(4). The procedure was regarded as "a virtually useless tool" by OLS officials. Interview with Duggan, supra note 12.

30. Guidelines, supra note 20 , at 7 .

31. Generally, the project's governing board was regarded as the institution respon. sible for drafting such standards in the first instance (presumably as part of its "policy. making" function). Guidelines, supra note 20 , at 3. This responsibility, however, was never formally pinpointed, and the CAA might just as well have been expected to create guidelines, since it was typically the formal grantee. See pp. 239.40 supra. The Guldelines mentioned factors which might be included in the standard: "income, depend. ents, assets and liabilities, cost of a decent living in the community, and an estimate of the cost of the legal services needed." Guidelines, supra note 20, at 7. However, the standards submitted by the projects-and approved by OLS-almost never included such factors explicitly. 
cited the provision in the Guidelines that "no standard should be inflexible." 32 Standards adopted by governing boards and approved by OLS consisted simply of income level cutoffs. There were wide variations among these standards, and major differences between projects in the same state or region that served areas with similar populations and local conditions. ${ }^{33}$ As a matter of unwritten policy, legal services officials often permitted the eligibility standard to be waived entirely if a client was unable to secure private counsel. ${ }^{3 t}$ But the conditions under which this might be allowed were never defined for the program as a whole in any form. Nor was there any clear determination of the criteria to be applied in determining the eligibility of groups or of individuals who might be "voluntarily poor." 35

There was a similar failure of policysetting with respect to the issue of services-the questions of what distinction was to be drawn between permissible and impermissible services, and what priorities would be established among different types of permissible services. Following the passage of an amendment in 1967 forbidding criminal representation, ${ }^{36}$ a Community Action Memorandum was issued interpreting per-

32. Guidelines, supra note 20 , at 7 .

33. For example, the Baltimore program had a standard of $\$ 3,800$ for a family of four, the one in Washington, D.C., had a cutoff at $\$ 5,200$. The program in San Jose, California, established an income level of $\$ 2,280$, while in San Diego the level vas set at $\$ 3,480$. These were the standards in use in 1967. Silverstein, Eligibility for Free Legal Services in Civil Cases, 44 J. URBan L. 549, 562 (1967). OLS officials contended that eligibility guidelines issued by the Office of Economic Opportunity did not apply to the projects. The two most important OEO issuances on eligibility vere: OEO Instruction No. 6004-1, Dec. 27, 1968, and, superceding this document, OEO Instruction No. 6004-1a, Jan. 30, 1970, 45 C.F.R. $\$ 10602-1$ (1971). The Instructions were intended by OEO officials "to be used for all those OEO-funded programs, whether administered by a grantee or delegate agency, which use the OEO poverty income guidelines as admission standards." OEO Instruction No. 6004-1a, supra. The Guidelines contained in Instruction No. $6004-1$ a set eligibility levels at $\$ 1,800$ for 2 non-farm individual, and $\$ 3,600$ for a non-farm family of four, with $\$ 600$ allowed for each additional member of the family. These Instructions, however, were never accepted by OLS or cnforced on legal services projects.

34. Typically, a legal services attorney was authorized to handle any case for which he had attempted two or more referrals to the private bar, regardless of other eligibility standards. Projects differed, however, in the number of referrals required, the system of referral established, and the individual given responsibility for final acceptance of the case.

35. See OEO Instruction No. 6004-2, March 22, 1969, 45 C.F.R. $\$ 1050.3-2$ (1971). Entitled "Limitation on Benefits to Those Voluntarily Poor," the Instruction provides that the program should not serve any individual who is "fully capable of supporting himself but chooses not to do so," unless the refusal is for "good cause." The question of what is "good cause" for purposes of this Instruction has never been resolved. The Guidelines imply that this group should not be provided with free legal services if they are able to afford a lawyer by "pooling resources." Guidelines, supra note 20, at 7. But the Guidelines add that "a flexible standard should be applied" involving consideration of the size of the group and the relative poverty of its members, and additional criteria. Id.

36. 42 U.S.C. $\$ 2809$ (a)(3) (1970). See note 16 supra. 
missible services to include representation of arrested persons before indictment or information, in parole revocation and juvenile court matters, in other specified types of cases and in "extraordinary circumstances." 37 The Memorandum acknowledged that numerous important questions were left unanswered, and promised that a more complete Instruction would be issued. But no further written guideline or standard was formulated, and legal services officials in several instances permitted a certain amount of criminal defense representation to be carried on. ${ }^{38}$ Policies pertaining to lobbying were equally uncertain. An Instruction on lobbying was issued prohibiting any activity which disrupted the ordinary business of a legislature or which involved demonstrations, rallies, picketing or forms of direct action aimed at a legislature. Also prohibited were campaigns of advertising carried on through the media and mass letter-writing or visitations calculated to influence legislators. ${ }^{30}$ This Instruction, however, failed to clearly determine the propriety of the most common and important lobbying activities of projects, largely because of an ambiguous proviso that restrictions were not to be interpreted to forbid "purely informational and educational activities." 40

-37. Community Action Program Memorandum No. 79 \& B(2)(6), Dec. 27, 1967. The memorandum interpreted the restriction to permit representation of arrested persons before indictment or information, parole revocation, juvenile court matters, procecdings concerning bail, alleged mistreatment of prisoners, civil contempt, criminal matters arising out of civil matters, and other "extraordinary circumstances." This memorandun began with the words "Pending more detailed instructions ...." Such instructions were never issued. On December 20, 1968, a draft issuance was released for review and comment to several hundred project directors and other officials. It was vehemently opposed by a vast majority as being too restrictive. A second draft dated March 27, 1970, was never issued for comment because of opposition to it from the Office of General Counsel in OEO. "Since the last draft," according to one account, "many others have been attempted and none has reached the point of being sent out as an Issuance. As a matter of fact, most have been thrown away in disgust before completion." Mcm. orandum from Steven Draisin, Summer Intern, to Fred Speaker, Director of OLS, $\Lambda$ ug. 11, 1971, re Policy Guidelines for Criminal Representation.

38. See description of grant to NOLAC in New Orleans, pp. 253-54 infra.

39. Community Action Program Memorandum No. 66, June 10, 1967.

40. Terry Lenzner informed OEO officials that an improved Instruction on lobbying was urgently needed, following complaints by Rep. Craig Hosmer with respect to the lobbying activities of the Legal Aid Foundation of Long Beach. One of the "grey areas," he suggested, was the propriety of lobbying activity directed at legislation affecting the poor not carried out on behalf of any particular client. Memorandum from Terry Lenzner, Director of OLS, to Donald Rumsfeld, Director of OEO, Aug. 25, 1970, guoted in Memorandum from Stephen Schultz, Summer Intern, to Fred Speaker, Director of OLS, Aug. 6, 1971. No additional guidelines were ever adopted, though Lenzner's suc. cessor, Fred Speaker, drafted a new set of proposed guidelines on the subject, and dis. seminated them for comment to various legal services project directors. Memorandum from Fred Speaker, Director of OLS, July 12, 1971, quoted in Schultz supra.

One report on the adequacy of the existing Guidelines commented: "For the past five years, legal services attorneys have been engaged in lobbying activitics. There have been little if any national directives encouraging this legislative activity; it has simply evolved." The report noted that 103 projects were "known to have engaged in some 


\section{The Failure of Responsiveness}

The legal services program never determined how responsive the program should be to its various constituencies. In the absence of such a determination, officials have had no basis for policysetting with respect to the structure and composition of institutions such as local governing boards. They have had no criteria by which to allocate representation, resolve competing claims of constituencies, decide the proper role of the bar or deal with CAA's. The result has been a lack of policysetting on matters involving the allocation of representation and influence. After the passage of the 1967 OEO amendments, requiring a minimum of one-third representation of the poor on CAA governing boards, the OLS required its own governing boards to conform to this provision. ${ }^{11}$ In addition, it required a majority of lawyers on most boards, but this requirement was never articulated in any official form, nor were more detailed specifications elaborated.\$2

The lack of policysetting created, in effect, a vacuum into which groups and individuals, representing primarily the professional community and community at large, moved to seize control and exert pressure. At the local level, governing boards of projects have been

form of legislative activity." Schultz supra. It recommended that guidelines be formulated to specifically permit legal services attorneys to contact individuals and groups and tell them of the effects of proposed legislation, maintain ongoing relationships with legislators, draft legislation, and perform other activitics, the propricty of which was uncertain. Besides Community Action Program Memorandum No. 66, a number of OEO Instructions deal with related issues-the application of the Hatch Act (18 US.C. $\S 594$ (1970)) to OEO employees (OEO Instruction No. 6907-1, Scpt. 6, 1968): participation by employees in unlawful demonstrations, rioting and civil disturbances (OEO Instruction No. 6907-2, Oct. 21, 1968, 45 C.F.R. \$ 1069.2-1 (I971)); and cmplojec participation in "direct action," such as "picketing, parades, or marches, sit-ins, rallies or assemblies." OEO Instruction No. 6907-3, Dec. 14, 1968, 45 C.F.R. $\$ 1069.1-1$ (1971). See also note 82 supra for a description of difficulties encountered in Albuquerque with respect to picketing and direct action activities.

41. A provision included in the Economic Opportunity Act of 1907 required that one third of the members of all CAA governing boards be "representative" of the poor. See Economic Opportunity Amendments of 1967, supra note 16, 42 US.C. $\$ 2791(\mathrm{~b})$. See also note 119 infra. In OEO Instruction No. 6005.1 this provision was interpreted to apply to the governing boards of all delegate agencies, including those of legal services projects, as well as the CAA boards. OEO Instruction No. 6005.1, Dec. 1 , 1968, Participation of the Poor in the Planning, Conduct and Evaluation of Community Action Programs, 45 C.F.R. \$ 1060.1-2(5) (I971). Nonetheless, OLS never specifically revised or rescinded the Guidelines to take account of the policy. The Guidelines stated that OLS "does not require a fixed proportion of the people to be served or their representatives on the policymaking board." Guidelines, supra note 20, at 4. The OEO Instruction No. 6005-1 "was not something flagged to the attention of legal services projects." Interview with Duggan, supra note 20 .

42. Interviews with Bamberger, Lenzner, Johnson, Speaker, supra note 14. Mrembers of boards are chosen in a variety of ways. Lawyer members almost all are appointed, either by local public officials, the local bar association, or the CAA. The representatises of the poor are often elected, and sometimes appointed by CAA boards. Some gorerning boards choose their own successors. Often, the lack of any length limit on period of service allows them to reappoint themselves. 
dominated most often by attorney members. ${ }^{43}$ Such members are often selected by officials of the local bar and almost invariably consider themselves representatives of the bar. They run meetings, formulate procedures by which decisions are made, chair executive committees, and usually head the boards.4 Second only to the bar, in terms of local influence, has been the community at large. Its representatives are "lay members" appointed by social service agencies, public officials, and the CAA's. Though such members sometimes claim (or are called upon) to express views of the client community, almost all owe their primary allegiance to the community at large. ${ }^{45}$ In order truly to represent the client community, it has been increasingly assumed, a representative must be poor himself. The representatives of the poor, however, are usually less thoroughly prepared for board meetings and are often inhibited by the procedures, place and scheduling of the discussion. ${ }^{40}$ The only representative of the legal services attorneys at board meetings is the director of the project, and directors have generally been barred from voting.

43. One source of the bar's power at state and local levels is the requirement that the associations be consulted prior to funding of a legal services project. 42 U.S.C. $\S$ 2809(a)(3) (1970). See Stumpf, Law and Poverty: A Political Perspective 1968 Wis. L. REv. 694. This requirement is applied through OEO Instruction No. 6140.1. Sec notc 25 supra. But the most important source of power has been the bar's participation, granted formally or informally, in the selection of governing board members. In a significant number of legal services programs-estimates range from thirty-five to fifty per cent-bar associations chose a majority of members of the governing board. Interview with Duggan, supra note 20. Informally, regardless of the board structure, they cxercise an important influence in the hiring and firing of employees, the appointment of a director, and the determination of project policies, particularly regarding cligibility. In many projects, according to the first Director of OLS, Clinton Bamberger, bar control was the "price" paid for establishing legal services. "Bar support wasn't absolutely necessary but we wanted it. Sure we negotiated. We wanted a majority of the board to be lawyers, though this didn't mean that all the lawyers had to be chosen by the bar." Interview with Bamberger, supra note 14.

44. Interview with Duggan, supra note 20.

45. The chief executives of social service agencies, whether public or private, have not been regarded by the poor as true representatives of their interests. Intervicw with Jean Cahn, in Washington, D.C., Sept. 16, 1971; and Interview with Maryellen Hamilton, President of the National Clients Council, in Washington, D.C., Sept. 16, 1971. Such executives may be heads of welfare departments, united funds, or other local charitable or religious groups. They are selected by officials, or by resigning members of the board. Legislatively, Congress has recognized that only representatives selected by the poor themselves can clain to represent this community. See 42 U.S.C. $\$ 2791(b)(2)$, $(f)(2),(3)(1970)$. This recognition is articulated even more clearly in the proposed legis. lation, which stipulates the minimum representation of the poor on local boards in terms of "member[s] of the client community." The Bill $\S 1012(4)$.

46. The domination of lawyers is a frequent complaint of the client community rep. resentatives, who contend they are "bossed around." Interview with Hamilton, supra note 45. As one observer has written: "There are many members of the bar who doubt the poor have much to contribute to the determination of the policies of a legal services program. . . . They also resist the idea that ethical decisions brought before the board should be determined in part by laymen. . . Most programs . . will be lawyer-run regardless of whether there are poor on the board." Pye \& Cochran, Legal Aid-A Proposal, 47 N.C.L. REv. 528, 571 (1969). 
At the national level, the program has been highly sensitive to the interests of the bar-though the bar, at this level, comprises a completely different set of organizations and officials. ${ }^{17}$ The influence of the community at large, perhaps equal to that of the bar, is exercised through particular Congressmen whose demands are usually on behalf of individuals or groups and relate to a particular project. The bar and the community at large dominate the National Advisory Committee (NAC), a consultative body composed primarily of lawyers, appointed and chaired by the Director of OLS and including the president, past president and president-elect of the American Bar Association. ${ }^{48}$ Legal services attorneys have played a significant role on the NAC, principally through representatives who are sympathetic to their interests. But the client community has had virtually no representation on this body and its interests often differ importantly from those of legal services attorneys. ${ }^{40} \mathrm{~A}$ National Clients Council, still in its formative stages, has been unable to command much influence or to form alliances with other organizations representing the poor. ${ }^{80}$

47. The American Bar Association is not related, in terms of membership, control or organization, to state and local bar associations. The ABA has strongly supported the program since its founding, but has insisted on a special relationship in return. This relationship has meant in effect an expectation of a semi-official role in running the program. In 1969, for example, the ABA insisted on the right to disapprove any nominee being considered by Donald Rumsfeld, then Director of OEO, for the position of Director of OLS. Rumsfeld refused to drop Terry Lenzner from consideration, though the ABA initially expressed reservations with respect to his qualifications, and proceeded to request his nomination by the President. The $A B A$ continued to play a major role in the National Advisory Committee, and provided important aid to Lenzner in a number of instances, such as the fight against the Murphy Amendment. See note 103 infra. See also SENATE REPORT, supra note I, at 29.

48. The procedures involved in the selection and operation of the NAC may well violate OEO Staff Instruction 1205-2, which prohibits any of the agency's advisory committees from being self-perpetuating. OEO Staff Instruction 1205-2, Nov. 23, 1971. This characteristic, however, reflects the assumption that the bar will have a special role on the NAC:

An important ingredient of the agreement between OEO and the bar was the establishment of the National Advisory Committee to Legal Services. As ABA President Edward Wright told the subcommittee of Manpover, Emplojment and Poverty on May 11, 1971: "The National Advisory Committee was later established pursuant to the understanding between OEO and the bar to assure the continued cooperation and support of the organized bar and to provide a voice for it in policies affecting the operations of the program."

SENATE REPORT, supra note 1, at 29-30.

49. Legal Services attorneys have been known to place a higher priority on some issues, such as their own status within the program, that are of less concern to the clicnt community. Moreover, on certain issues the interests of the attorneys and the poor may be in direct conflict or at least may be felt to be so. Recently, for cxample, there have been increasing complaints from clients about attornejs who "cxploit" clients to launch sweeping law reform actions, when the individuals may be secking much more limited solutions to their problems within existing laws. The clients accuse the attornejs of taking law reform "ego trips" at their expense. The National Clients Council has begun compiling documentation on this problem, and plans to make it a major issue. Interiev with Hamilton, supra note 45 .

50. The National Clients Council (NCC) is an organization whose membership is composed of individuals eligible for free legal services and whose purpose is "to act as 


\section{E. Failures of Policysetting and Responsiveness: Examples of Political Interference}

Although generalizations about political interference are difficult to make, a common pattern is discernible. Initially, an individual or group believes that its power or interests are threatened by particular activities of the legal services project. The individual or group attempts to forestall or eliminate these activities by controlling the project or exerting pressure on it. The conflict is thus manifested in a public, political controversy. When controversy erupts, however, public attention is focused on some particular policy problem, e.g., the structure of legal services institutions, eligibility or services, rather than the broader claim to representation implicit in the position of the challenging party. The challenging party uses the policy issue as a weapon against the project or the program as a whole by charging that the activity in question is improper. This policy issue may trigger other weapons such as a veto (or veto threat) of the project's grant by the governor or a cutoff (or threat thereof) of contributions by local organizations. Often the conflict escalates to the national level, as Congressmen, Senators and federal officials are enlisted on either side. Officials of the project and OLS attempt to defend the propriety of the project's activities, but their arguments are undermined by the ambiguity or absence of standards and guidelines and by a resultant inability to distinguish legitimate from illegitimate pressures. Their actions take on the appearance of administrative fiat. The result is often a decline of self-confidence as project attorneys and bureaucrats, once-burned, trim their sails. This pattern can be illustrated in the three major policy areas: guidance and supervision, eligibility, and services.

a liaison between the poverty community and the lawyers working in legal aid/services." National Clients Council Funding Proposal for 1972, submitted with letter from Maryellen Hamilton to Fred Speaker, June 24, 1971. The NCC had a budget of approximately $\$ 118,000$ in fiscal year 1971 , funded almost entirely by OEO. In many instances, it operates as a kind of ombudsman on behalf of the poor. Recently, for example, it sur. veyed representation of the poor on legal services governing boards and found "many boards around the country with no clients on them. The Clients are represented by either attorneys or someone who really cannot speak for the poor." Id. "The national leadership in the NCC is chosen in a series of statewide and regional mectings of clicnt delegates, who are themselves chosen by the governing boards of local projects. The NCC claims that 2,000 representatives of the poor throughout the United States "participate" in the organization. Id. But there have been serious questions as to the representativeness of the national leadership, and the actual number of clients active in the organization's affairs. Thus far, attempts to align the NCG with the National Welfare Rights Organization or National Tenants Council have been unsuccessful. In. terview with Jean Cahn, supra note 45. 


\section{Guidance and Supervision}

Two kinds of groups in particular, local bar associations and CAA's, have attempted to dominate local governing boards or to usurp their responsibilities for guidance and supervision. Often they have succeeded, because of OLS' failure to formulate a conception of how political power should be divided. Had such an allocation been even roughly determined in advance, some of these demands might have been resisted. The predominance of bar associations and CAA's has constituted a failure of responsiveness to other important constituencies.

In Houston, the governing board of the Houston Legal Foundation (HLF) was composed of prestigious members of the bar and headed each year by the outgoing president of the Houston Bar Association. The board refused to permit community education, law reform or group representation; ${ }^{51}$ large numbers of applicants were rejected, and of those accepted at least two thirds were classified as domestic relations cases. OLS officials recognized that the defects of the project, described in numerous evaluations, were in large part the result of responsiveness solely to the professional community, at the expense of the interests of the poor and the legal services attorneys. tempting to alter the situation, the bargaining position of OLS was weakened not merely by the ambiguity of guidelines on the substantive issues, but also by the lack of a normative framework according to which the bar's influence could be labeled excessive. HLF board members contended that neither the project's policies nor its board structure violated any written OLS policy or standard. The weakness of the OLS position emboldened HLF, and caused OLS officials to shy away from a funding cutoff or any other dramatic move

51. These terms have never been officially defined but are commonly used within the legal services program in evaluations and memoranda. See note 23 supra. Group representation consists of services provided to an organization or association of low income individuals who are generally residents of a particular ncighborhood or area. Law reform may be defined as representation provided to a low income group or individual with the primary objective of changing a law or legal interpretation affecting the poor generally and usually involving elemental questions with respect to the distribution of power or wealth. Such representation is distinguished from individual casework or service, which has the primary objective of improving the situation of a low income group or individual under existing law. The two, of course, overlap. But the two activities are separable in terms of primary objective. For an illuminating discussion of law reform and legal services generally, see Hazard, Law Reforming in the AntiPoverty Effort, 37 U. Chi. L. REv. 242 (1970).

52. An evaluation in June 1971, reported that the governing board had "an image of total control by the Houston Bar Association." Aucrbach Associates Inc. Evaluation Report, the Houston Legal Aid Foundation, May 12-15, 1970. "Until 1969, the goreming board categorically refused to permit any representatives of the poor to sit on that body." Interview with Duggan, supra note 20. 
which might have precipitated a public confrontation exposing the lack of policysetting. ${ }^{53}$ The bar succeeded in maintaining its control for more than four years; the vacillation of OLS ultimately resulted in a bitter and disruptive climax to the dispute. 54

Similar situations occurred in Charlotte, North Carolina, 55 Volusia County (Daytona), Florida,56 Tallulah, Louisiana, ${ }^{67}$ and Baltimore,

53. See Letter from Frank Jones, Deputy Director of OLS, to W. Ervin James, Chairman of the Board of Directors of the Houston Legal Aid Foundation, May 30, 1970 .

54. Under a threat of a funding cutoff, the governing board reconstituted itsclf in 1971. Even then, however, the bar continued to exercise substantial indirect influcnce. See Aucrbach Evaluation, supra note 52. Many OLS officials feel that the National Office should have moved more decisively, but was constrained from doing so by lack of standards. "Those were heavy-weight guys on the board and when you go against them you've really got to have your ducks in a row." Interview with Duggan, supra note 20.

55. In Charlotte, the President of the Charlotte Mecklenburg Bar Association chose eight of the fifteen members of the governing board of the project, who in turn chose the remaining seven as representatives of the target community. The board insisted on prior approval of all suits, case by case, and refused as a general matter to allow any class actions or group representation, or any activities involving economic development and community education. A limit of $\$ 300$ was set on all claims, preventing attorneys from taking actions to the federal district court. The project was "used as a dumping ground for unwanted cases" by private attorneys, and the caseload consisted in large part of family relations problems. Auerbach Associates Inc., Evaluation Report, Legal Aid Socicty of Mecklenburg County, June 22, 1971. The project was criticized as "weak and ineffective" by a number of evaluations. OEO, Legal Aid Society of Mecklenburg County, Evaluation Report, 1969; Auerbach Evaluation supra. Following the firing of a staff attorney for filing a police brutality suit, OLS officials attempted to perstiade the project to reconstitute the board. A compromise was reached: the board removed some of the restrictions on project activities, but its membership and method of selection remained unchanged. Despite the removal of formal restrictions, attorneys are scvercly inhibited by the board. They are "young, bright and energetic, but are frightencd of the board's power. . . They have yet to take on a case significant cnough to arousc curiosity or retaliation from the Board." Auerbach Evaluation supra. Many OLS of. ficials believe that the national office could have succeeded in altering the structure and composition of the board if guidelines and standards could have been brought to bear. Interview with Bradley, supra note 15.

56. When OLS officials demanded that the board of the Volusia County Legal Services project be reconstituted, as a special condition attached to the 1970 grant, the President of the VCLS board demanded a hearing on the grounds that "no action by the prescit board" had been cited which could be deemed contrary to "standards set out by the Office of Economic Opportunity." See Telegram from Terry Lenzner to Dan Bradley, Regional Director of OLS, Southeast Region, Sept. 21, 1970; Letter from Frank Jones to Bernard Strasser, Chairman VCLS board, Sept. 2, 1970; Letter from Bernard Strasser to Frank Jones, Oct. 1, 1970. The board, dominated by the bar association, had imposed low eligibility standards so as to produce a high (thirty per cent) rejection rate; it had also restricted attorney activities, and provided for segregation of personnel in scparate offices by race. The project had been rated "very troubled" and in need of "drastlc revision." OEO, Annual Evaluation Report of Volusia County Legal Services, 1970. "Thic lack of standards and guidelines prolonged the dispute: VCLS refused to comply with the special condition to the 1970 grant, and local opponents contacted Senator Edward Gurney, Mayor Richard Kane of Daytona Beach, and officials of the Florida Bar $\Lambda$ sso. ciation to take their cause to high officials of the Nixon Administration. Sec Letter from Senator Edward J. Gurney to Donald Rumsfeld, Aug. 18, 1970; Letter from Richard Kane (et al.) to Senator Edward Gurney, July 25, 1970; Letter from Marshall R. Cassedy, Executive Director, Florida Bar Association to Donald Rumsfeld, Oct. 27, 1970. OLS officials eventually succeeded in altering the composition of the board, but the delay and disruption resulted in the demoralization and departure of many attorneys. Interview with Bradley, supra note 15.

57. A first attempt by OLS officials to reconstitute the board of the Delta Legal Aid Society, in Tallulah, La., failed because the "lay members of the board were hand-picked 
Maryland.58 In each of these cases, bar domination of the governing board produced restrictions on the project's activities: in Charlotte, a prohibition on group representation; in Volusia County, a limitation on law reform; in Tallulah, apparent restrictions on certain types of suits; in Baltimore, a restriction on the number and location of neighborhood offices.

In Chicago, restrictions were set by the local CAA-the Chicago Committee on Urban Opportunity (CCUO), dominated by the mayor -on its delegate, the Legal Aid Bureau (LAB). ${ }^{60}$ Restrictions affected the location of $L A B$ offices, intake procedures, representation of groups, and suits against municipal agencies. On a number of issues raised, such as the location of offices and intake procedures, the absence of guidelines and standards undercut OLS' argument for change. ${ }^{\circ 0}$

by the attorneys." Letter from Winston Webster, Director, Planning, Technical Assistance and Evaluation, OLS, to George Wall, Jr., President of the Board of Directors Delta Legal Aid, Aug. 4, 1971. The lay members, as a result, were "unassertive, nonvocal, and wholly unrepresentative of the poverty community." And the restrictive policies of the board remained substantially unchanged: "The board has, in its fervent desire to protect themselves against the illusory economic threat . . . rendered the projeet totally ineffectual. It was felt that the board has constrained the project to handle only innocuous cases and has prevented LAS from pursuing law reform, economic development, community representation and community education." Id. The first attempt to reduce the bar's influence having failed, OLS threatened that funds vould be cut off after October 1, 1971, "unless the board is restructured in order to include four persons who are representative of and democratically sclected by the poicrty community:" Id. The vagueness of the Guidelines allowed DLAS to arguc, following the first attempt, that it was in compliance, since no standard or guideline required that lay members be "assertive" or "vocal," or defined the meaning of "representative." It is not clear, at this writing, whether the second attempt has met with greater success.

58. In Baltimore, the City Bar Association was granted power in the by-laws of the Legal Aid Bureau to control the number and location of neighborhood legal aid offices. OLS officials sought to force the bar to relinquish this poiser, since it had the cffeet of restricting services to two offices, though fourteen had been planned when the program was organized in 1965. But the bar's power had been the result of a specific agreement between bar officials and OLS, as the "price" of bar approval of the project. Interview with Clinton Bamberger, former Director, OLS, in Washington, D.C., Aug. 25,1971 . The lack of standards and guidelines permitted such an agreement to be made and made it difficult to undo. The bar had control of the project's governing board, through appointment of fourteen out of its twenty-eight members, and succeeded in resisting demands from OLS that the project's activitics be expanded to other offices. OLS contended that the bar's power was "out of line with national policy." Memorandum from Francis Duggan to Terry Lenzner, July 21, 1970. But no such national policy had ever been defined or articulated in writien form. The only concession made b; the bar was to permit the opening of two new offices. See Baltimore Sun, Oct. 6, 1970, at 22, col. 5. See also Derby, Public Assistance in Baltimore City 26 Mp. L. REv. 328 (1966). Interview with Lawrence Hamblen, Regional Director of OLS, Mfiddle Alantic Region, in Washington, D.C., Sept. 15, 1971.

59. Mayor Richard Daley is Chairman of The Chicago Committee on Urban Opportunity, the board of the CAA. The CAA was described in its 1969 Annual Report as "an operating agency of the City of Chicago." The Cuicuco Cosussrme ox Unnus Opportunity, 1969 ANNUAL RePORT, WTth the Peorle (1969), reprinted in 1971 Senate Hearings, infra note $106, \mathrm{pt} .1$, at 254.

60. Project attorneys objected that the location of offices in CCUO centers and the "urban life interview" required as a part of "intake" by CAA officinls both inhibited clients and associated attorneys with the municipal agencies in the minds of many poor 
Even where CCUO restrictions seemed to violate guidelines such as the restrictions on suits against city agencies the written policy was so vaguely stated as to give the CCUO a colorable case. ${ }^{01}$ The most effective weapon at OLS disposal, direct funding of the legal services project, was virtually useless because no policy had been set on the conditions under which direct funding would be justified. A bitter bureaucratic struggle ensued within OEO, as well as between the local Community Action Agency and OEO, on whether the project should remain a delegate. The local Community Action Agency retained control until $1970 .{ }^{62}$ In many other projects interference by the CAA has taken the form of a demand for an administrative levy or tax on the legal services project $^{63}$ in supposed compensation for bookkeeping, payroll and other services rendered. ${ }^{64}$

people. The restrictions on group representation and suits against the city government seemed to have a purely political purpose: the CCUO, controlled by Mayor Dalcy, re. fused to allow any activity that threatened the dominance of the local political machinc. The division of attorneys among all the centers prevented specialization among attorneys and an appropriate division of labor, as well as privacy for consultation with clients. Evaluations concluded that the restrictions ought to be removed, but could point to no specific written policy that precluded them. See Memorandum from Frank Joncs to Terry Lenzner, June 15, 1970; OEO Evaluation Teams, Annual Reports, 1966.69. See also Chicago Bar Association, Council of Lawyers, Special Investigation, February, 1970.

61. Cf. Letter from Mrs. Murrel Syler, Director of the Chicago Committce on Urban Opportunity, to Terry Lenzner, May 15, 1970. See also Memorandum from Frank Carlucci, then Assistant Director of OEO for Operations, to Wesley Hjornevik, Deputy Director of OEO, Feb. 18, 1970. Many officials within OEO, particularly those associated with the Community Action program, felt that the restrictions were not improper, or at least not explicitly contrary to OEO policy. This was argued, for example, by Frank Carlucci, who had responsibility for the Community Action program as Assistant Director of OEO for Operations.

62. Officials within the OEO associated with the Community Action Program insisted that there should be direct funding only in three cases: (1) where there was no $\mathrm{C} \Lambda \Lambda$ covering the appropriate geographical area, (2) where the CAA declined to be thic grantee, or (3) where the CAA was "so ineffective" and "incapable" that the CAA itself should be suspended or terminated. Memorandum from Frank Carlucci to Donald Rumsfeld, Feb. 27, 1970. In the case of Chicago, they contended, none of these condl. tions was present. OLS officials countered that the general competence of the CAA should not be the major criterion, but rather the nature of the relationship of the $\mathrm{CAA}$ to the project, though they agreed that the "burden of proof of the desirability and/ar necessity for direct funding" should fall on the party seeking it. Memorandum from Terry Lenzner to Wesley Hjornevik, July 17, 1970. The CCUO enlisted Mayor Dalcy, the Cook County Bar Association, Representative Roman Pucinski and other local Congressmen to exert pressure on OEO against direct funding. OLS prevailcd, and on June 8, 1970, Donald Rumsfeld decided to fund the LAB directly. See Telegram froin Frank Jones to Mayor Daley, June 8, 1970. But the dispute severely disrupted LAB activities, and the internal divisions scarred relationships within $\mathrm{OEO}^{\prime}$ and lowercd morale in the project. Interview with William H. McClaskey, Regional Director of OLS, Great Lakes Region, OLS, by telephone, Aug. 17, 1971. The general issuc of direct funding was never settled.

63. Many CAA's charge fees for supportive activities, but OLS officials have never determined what percentage of the project budget would be fair payment. As a result, the levies have varied greatly in amount, from a token amount in some cases to fifteen per cent of the project's budget in others. Interview with Duggan, supra note 20.

64. The kinds of problems encountered by numerous CAA's as a result of the lack of policysetting on such levies is illustrated by the tumultuous dispute in Grand Rapids, Michigan, where OEO officials declined direct funding until the CAA withheld all 


\section{Eligibility}

In Dallas, the Dallas Legal Services Project (DLSP) provoked the ire of local officials and Congressmen by representing clients who were deemed "anti-establishment." The opponents charged that the project was representing non-poor and ineligible clients, citing particularly the representation of an editor/publisher of an underground newspaper. They argued that the client should have been ruled ineligible because he was "voluntarily poor"; he was a college graduate and the son of a wealthy manufacturer. He had been disinherited by his father, however, and was earning less than \$100 a month.os OLS officials themselves were in a quandary as to the publisher's eligibility: representation of such a client, as Deputy Director Frank Jones wrote, was "an accurate reflection of existing practice" but not "existing policy" because there was "no formal policy statement" on the voluntarily poor, and the "existing guideline is indeed vague."00 The reaction of OIS officials was inconsistent and unsupportive: they first demanded that the case be dropped, then encouraged it to go forward." Nevertheless,

money from the project for nine months, creating an emergency situation and nearly destroying the project. The Grand Rapids CAA demanded a levy of five per cent of the project budget, but evaluations reported that the services it performed vere minimal, and that the "most pressing, serious project weakness" was the "conflict with the Community Action program." Auerbach Associates, Inc., Evaluation Report Legal Aid Society of Grand Rapids, Michigan, Oct. 23, 1970. OLS officials had no answer to the arguments of CAA officials that such charges were justified for "central administrative expenses" (Letter from Raymond Tardy, Director, Community Action Program, to Stewart Christian, Director of Legal Aid Society of Grand Rapids, June 12, 1970), though craluations recommended that the levy be disallowed and that legal services offices be separated from the CAA centers in order to "preserve as far as possible the normal attorney-client relationship." Auerbach Associates supra. The withholding of funds by the GAA was an attempt to compel the project to continue the administrative relationship. Numerous meetings were held at all levels of the program, one of them including W'esley Hjornerik and Terry Lenzner on September 14, 1970. The history of these meetings and summaries of the major documents involved demonstrate that much of the nine month delay in decision-making was due to internal uncertainty as to the justification for such administrative levies in general and in this project in particular. See Memorandum from William McClaskey to Arthur Reid, Acting Director of OLS, re Resume of Problems of Grand Rapids ISP with CAA, Feb. 18, 1971. See also Warren Fox and Charles W. Quick, Evaluation Report, Feb. 23, 1970.

65. The publisher of Dallas Notes was sued under the state obscenity law for the June 3-16 issue, which carried on its front page a photograph of a nude man, front view. He was at the head of a march sponsored by a local radio station to support mini-skirts and protest longer hemlines. Dallas Notes, June 3.16, at 1. Legal Serriees attorneys appeared on behalf of the publisher, Brett Stcin, in an attempt to remove the case to a federal court, but were unsuccessful. Representative James Collins and Senator John Tower both protested the representation. See Letters from James W. Griftith, Regional Director of OLS, Southwest Region, to Congressman James Collins, July 2 , 1970, and Senator John Tower, July 20, 1970. See also OEO Evaluation of Dallas Legal Services Project, Aug. 7, 1970.

66. Letter from Frank Jones to Fred Condor, Chief of Southwest Region, OLS, Nov. 5, 1970.

67. OLS officials initially demanded that the case be dropped but the DLSP director, Ed Polk, argued that the publisher should not be denied services because he had chosen 
the opponents' attacks had an important psychological effect on the project, demoralizing the staff and arousing fears of funding reductions in response to congressional pressure. Moreover, the incident and the indecisive response of OLS encouraged other critics. ${ }^{68}$

Much the same pattern was evident in the controversy involving the Western Center on Law and Poverty (Western Center) in Los Angeles, which was attacked by local and state officials for its suit against the California Youth Authority on behalf of thirteen employees who had been suspended or demoted. The national office agreed with critics of the program that the clients' "incomes place them in the middle or upper income brackets." 60 But the Western Center argued that its eligibility criteria were consistent with OEO Guidelines, even though the criteria specified no income level and allowed representation in any case which had been declined by three private attorneys. ${ }^{70}$ Though

a low-paying profession. He contended that the Southwest Regional Office of OEO had assured him that the publisher was eligible. Letter from Ed Polk, Dircctor of DLSP, to Terry Lenzner, Oct. 29, 1970.

68. Interview with Duggan, supra note 20.

69. Telegram from Terry Lenzner to Martin Levine, Chairman Board of Directors, Western Center on Law and Poverty, Oct. 22, 1970. The telegram demanded that within twenty days the cases be referred to private counsel or, if that were not possible, that the legal services attorneys withdraw from the cases with permission of the court on the ground that the attorneys were not authorized to provide represcntation to these clients. "It is our view," Lenzner said, "that the center may not represent other than low income persons. There can be no question that this conclusion is requircd by the Economic Opportunity Act and by Legal Services guidelines." He added: "Ilic provision of free legal services to those whose incomes place them in the middle or upper income brackets is clearly in violation of the purposes and goals of the Economic Opportunity Act." 'The suit was filed on February 26, 1970, for damages, injunctive relief and declaratory relief on behalf of clients who claimed they had been disciplined as a result of their efforts to organize and maintain the Coalition for Correctional Reform, aimed at uniting individuals involved in the correctional process to bring about change. Alderete v. Terhune, Civil No. 70-131-TH (C.D. Cal., filed Feb. 26, 1970). Attorneys of the Western Center attempted to refer the case to numerous attorncysthrough the Los Angeles Bar Association, the American Civil Liberties Union, and other groups. The employees had been disciplined for complaining of conditions alleged to exist in the wards. See Memorandum from Ralph Segura, attorney at the Western Center on Law and Poverty, to Terry Hatter, Director of the Center on Law and Poverty, re Alderete v. Terhune, Oct. 7, 1970.

70. Telegram from Martin Levine to Terry Lenzner, Oct. 26, 1970. A standard based solely on income, Levine argued, "is not contained in the Economic Opportunity $\Lambda \mathrm{ct}$ and is contrary to the OEO legal services guidelines, contrary to the standards of the National Legal Aid and Defender Association, and contrary to the eligibility critcria which you have approved for our program in 1969 and 1970." Paragraph 4 of thc eligibility criteria adopted by the Western Center Board of Directors, and approved in 1969 and 1970 by $O E O$ as part of the refunding application, provided: "Where three attorneys have indicated they will not take the case, the case may be accepted by the Center with the approval of the Director." Contrary to Lenzner's contention, Levine said that the Director had approved this case, after "over a dozen attorncys were con. tacted." In the telegram, Levine argued that "standards which allow determinations of financial eligibility solely on the basis of specific income levels or the possession of specific assets, i.e., automobile, home, etc., should be eliminated." Otherwisc, there would be "a major, important contraction in the availability of legal services to the poor." See also Auerbach Associates, Inc., Evaluation Report, Western Center on Law and Poverty, June 23, 1971. The evaluation gave the Center an overall rating of "good," and particularly praised its law reform work: "The Center has made its greatest impact 
the suit was allowed to proceed, the vagueness of the Guidelines reduced OLS officials to impotence as the controversy raged, and also undermined the project's attempts to justify its policies. ${ }^{71}$

\section{Services}

In New Orleans, officials led by Rep. Joe Waggoner, Jr., had a record of hostility to the New Orleans Legal Assistance Corporation (NOLAC), primarily resulting from its aggressive representation of the poor in suits against local interests. They charged that NOLAC attorneys were defending twelve members of the black militant National Committee to Combat Fascism (NCCF), who had been arrested after a two-day shoot out with New Orleans police. ${ }^{72}$ The project contended that its activities in the case consisted only of representation in the bail reduction hearing and a request for a preliminary hearing. ${ }^{73}$ Both the project and OLS officials were handicapped in countering criticism by the fact that the Guidelines did not specify whether such activities were permissible. ${ }^{i 4}$ But even more damaging to their position

in Southern California through its law reform activities and has camed a reputation for high quality legal work." For a general description of Western Center activities, see Western Center on Law and Poverty, A Report to the U.S. Office of Economic Opportunity In Support of Refunding the Western Center on Law and Porerty 1971-1972, February 18, 1971.

71. A comparable situation occurred in St. Louis, where Goiernor William Hearnes of Missouri vetoed a $\$ 390,359$ grant for the Legal Aid Society of St. Louis, charging that the project had represented rent strikers in public housing, a black militant who was involved in church confrontation and black students accused of mutilating an American flag. All of them, he contended, were ineligible. OLS officials urged OEO Director Donald Rumsfeld to override the veto, but their arguments lost considerable credence when they were asked to justify the project's activities in terms of guidelines and standards. An investigation produced evidence that a number of the clients vere, in fact, "clearly ineligible." Memorandum from William Barvick, Regional Director of OLS, North Central Region, to Terry Lenzner, Dec. 24, 1969. Questions were raised as to the content, as well as enforcement of the St. Louis standard. The failure to clarify and enforce the Guidelines, supra note 20, made it much more difficult for Rumsfeld to resist criticism of the project from local officials. See Letters from Senator Thomas F. Eagleton to John Danforth, Attorney General, State of Missouri, Dec. 20, 1969, and from Terry Lenzner to Senator Thomas F. Eagleton, Dec. 19, 1969. Though he crentually decided to override the veto, his delay in doing so undermined morale in the project. More important, as a concession to the critics, eight special conditions were attached to the grant. Telegram from Terry Lenzner to Don Thomason, Regional Director of OEO, Great Lakes Region, Jan. 6, 1970.

72. Letter from Representative Joc D. Waggoner, Jr., to Donald Rumsicld, Oct. 5, 1970. Waggoner demanded to know whether Rumsfeld "condoned" the project's service to NCCF, which he said was an organization modeled after the Black panthers.

73. Letter from John Nelson, Chairman of the Board, New Orleans Legal Assistance Corporation to Terry Lenzner, Nov. 6, 1970.

74. Community Action Program Memorandum No. $79 \S B(2)(6)$, Jan. 15, 1963, implied that such representation was legitimate, since it preceded the indicument or information stage. Yet the Memorandum was not entirely clear on this point. The issue was complicated by the fact that Barry Portman, Acting Director of NOLAC, had specifically requested permission to represent the NCCF clients in a call to Fred Condor, Acting Director of OLS, Southwest Region, on September 18, 1970. Condor had cxpressed no 
was the disclosure that they had failed to enforce the Guidelines in several previous cases involving clear violations. The ambiguity of the standards, combined with the failure of enforcement, forced the OLS to make serious concessions (including the suspension of two attorneys) ${ }^{75}$ The local project, and indeed the program as a whole, was severely shaken by these concessions. As a direct consequence of the attack, ${ }^{70}$ the two top officials of OLS were fired, a tremendous blow to the entire program. ${ }^{77}$

objection to NOLAC's involvement in the criminal cases. The NOLAC officlals argued that such representation would be within the Memorandum because of the practical unavailability of adequate defense counsel in the Orleans Parish Criminal Court, bccalisc of provisions in the NOLAC 1970 work plan providing for such criminal representation (which had been approved by legal services officials) and finally because of tacit ap. proval of previous criminal representation reported in NOLAC quarterly reports.

75. Initially, OLS threatened suspension or termination of the project if NOL $\Lambda \mathrm{C}$ had violated the criminal representation Guideline. A full investigation showed that OLS had to take a share of responsibility for the violation-if indeed it actually occurred -for its failure to clarify or enforce the Guideline previously. Nevertheless, in order to mollify opponents, OLS imposed a number of special conditions on the project. Letter from Terry Lenzner to John Nelson, Nov. 11, 1970. The restrictions, even if intended as only symbolic, might have had a significant chilling effect. Morcover, the dismissal of the two attorneys was publicized throughout the community and the legal services program.

76. Opponents were not appeased by the OLS concessions; nor was Dircctor Rumsfeld pleased with the handling of the affair by OLS. The firing of Terry Lenzner on November 20, 1970, was a direct result of his refusal to impose more stringent restric. tions on NOLAC. Interview with Lenzner, supra note 15.

The failure to enforce a clear policy on criminal representation, as well as in other areas, may sometimes give the appearance of official sanction to very questionable practices. In the case of Upper Peninsula Legal Services (UPLS) in Michigan, for examplc, evaluations reported that criminal litigation constituted some twenty to twenty.five per cent of the caseload in both 1969 and 1970. John D. Kettelle Corporation, Evaluation of Upper Peninsula Legal Services Inc., March 4, 1971. "As UPLS has become more confident of OLS's tacit allowance of its misdemeanor involvement," one cvaluation reported, "it is increasing." Id. The reason for such "tacit allowance" by the legal services re. gional officials, who were aware of the criminal representation, had been the shortage of lawyers in this vast and sparsely populated area. See Memorandum from Douglas Martin, staff, Office of Legal Services to Terry Lenzner, June 4, 1970. Regional offichals argued that the courts appointed and paid the attorneys in felony cases. Representation in misdemeanor cases did not violate the statute, they argued, becalise persons accused of a misdemeanor in Michigan are proceeded against by a simple written complaint signed by a police officer, without indictment or information. Id. Project officials argued that "a person accused of a misdemeanor would in many cases lose his job because he cannot drive to work." Id. The evaluation urged that "OEO should makc some rational and explicit decision on the increasing amount of criminal representation which UPLS is doing." Kettelle Evaluation, supra.

77. A controversy as to the propriety of services also erupted in Camden, N.J., where attorneys for Camden Regional Legal Services (CRLS) filed suit in federal court against two major urban renewal projects in August, 1970 alleging that city plans wottld result in destruction of a substantial amount of low income housing without sufficient relocation, in violation of federal law. Camden Coalition v. Nardi, Civil No. 1128.70 (D.N.J., filed Aug. 19, 1970). See Housing Act of 1969, 42 U.S.C. $\S 1451$ (c)(1) and (2) (1970). The plaintiffs included eleven civil rights and community groups and ten persons repre. sentative of the class of poor people adversely affected by urban renewal. The defendants included Camden's mayor and city council, the Camden housing authority, HUD, the U.S. Department of Labor, and others. In the fall of 1971 work on the projects was halted as the suit made it impossible for the housing authority to convey clcar title to the developer. David H. Dugan, III, Director, Camden Regional Legal Serviccs, Inc., A 
The charges of the state bar association against North Mississippi Rural Legal Services (NMRLS) centered in large part on the issue of services: whether NMRLS should be permitted to concentrate its resources on law reform suits. The absence of guidelines setting forth priorities between law reform and other forms of service such as individual casework made it more difficult for the local and OLS officials to justify the project's record in terms of OEO policy. ${ }^{78}$ The state bar

Detailed Account and Analysis of Vice-President Agnew's Recent Involvement with Camden Regional Legal Services, Feb. 10, 1972.

The mayor of Camden and Representative John Hunt complaincd that CRLS should not be allowed to block the city's urban renewal and road construction program. Sec Letter from Rep. John Hunt to Donald Rumsfeld, Feb. 5, 1970; Letter from Joseph M. Nardi, Jr., Mayor, City of Camden, to Donald Rumsfeld, Oct. 23, 1970; Letter from Joseph Nardi, Jr. to David Dugan, III, Oct. 23, 1970; Letter from Joseph Nardi, Jr. to Frank Carlucci, Director, Office of Economic Opportunity, May 6, 1971. In his letter to Rumsfeld, Nardi charged that the suits against the city represented a "complete disregard of the responsibility given to representatives of Legal Services. . . I wish to register my opposition to any continued funding of this program and $I$ am notifying each of the congressional delegation which represents this district of this concern..." Hc charged that the Assistant Director of the Camden project, Peter J. O'Connor, was making "an intensive effort to disrupt the community and to completely disregard detclopment in the city of Camden." Letter from Joseph M. Nardi, Jr. to Petcr O'Connor, Assistant Director Camden Regional Legal Services Inc., Oct. 23, 1970. The president of the Camden City Council wrote to Vice-President Agnew in December, claiming Urat CRLS was "attempting to destroy the government and the establishment." Letter from Elijah Perry to Vice President Agnew quoted in Dugan, supra. When Agnew traveled to a speaking engagement in New Jersey in January 1972, Camden public officials met vith him to solicit support. Fred Speaker, Director of OLS, then made his own investigation in Camden. In a thirty-four-page report to the Vice-President, Speaker concluded that CRLS was operating within federal guidelines and urged no further outside involvement in the matter. Interview with David Dugan, in New Haven, Conn., Feb. 22, 1972.

Nevertheless, Agnew decided to meet with all partics to the controicrsy. On Fcbruary 1, 1972, he met with David Dugan, OEO Director Philip Sanchez, Camden Mlayor Joseph Nardi, three other city officials, Representative Hunt, representatives of Camden's major industries, and others. Dugan, Account and Analysis, supra. Agnew began by declaring that he had no intention of interfering with the pending litigation in any way, but he later became very critical of the legal services attornejs, stating:

Mayor Nardi has a greater right to claim that he represents your clients than you do because he earned that right at the polls. We don't even know at this stage ... how the client came into the client-counselor relationship.... I'm not making any accusations. I'm merely expressing a great fear that government is going to become impossible if every time an elected official attempts to carry out what needs to be carried out that he's faced with court proceedings. .. . I think if you sit and forget the technicalities of your legal position for a minute and listen to these councilmen and listen to these gentlemen who represent the business community . . . you might be less militant in adhering to ... the total extent of your Iegal right in crery instance, and more conciliatory toward reaching a result that will allow the City of Camden to resuscitate itself, as it lies gasping.

Transcript of Meeting in Vice-President Agnew's Office, Feb. 1, 1972. The Vice-President's meeting, and his subsequent remarks on NBC's "Today" show, provoled a national controversy. See N.Y. Times, Feb. 2, 1972, at 1, col. 4; N.Y. Times, Feb. 6, 1972, $\$$, at 3, col. 3; Press Release, Transcript NBC Today Show Interview with the Vice President of the United States (Feb. 8, 1972).

78. The project had been rated one of the best in the nation, recciving an overall grade of 11.3 on a scale of 12 in its most recent evaluation. "The craluation team vias impressed by this project's law reform activity, its excellent attorneys, and its image in the poverty community. These would have been viewed favorably in any cnvironment; but the fact that the project was operating successfully in Mississippi was felt to be remarkable." Auerbach Associates, Inc., Evaluation Report: North Míssissippi Rural 
conducted an investigation that employed methods of a very questionable nature. ${ }^{79}$ But legal services officials had often used similar meth ods in their own evaluation reports. In the absence of investigative standards, they had no basis for justifying their own techniques, much less for impugning the bar association's investigation. ${ }^{80}$ Representatives of the bar carried their attack to the Director of OEO and the White House staff, demanding that the project be gutted and replaced by a bar-operated judicare project. Both the Director and the White House staff placed substantial credence in the charges of the bar because OLS officials were unable to defend the project's activities in terms of guidelines and standards. ${ }^{81}$ OLS succeeded in resisting the bar's challenge and vindicating the project only after a lengthy investigation which imposed substantial costs in money, energy and staff morale..$^{82}$

Legal Services, Aug. 16, 1971. Nonetheless, law reform was not among the five objectives mentioned in the Guidelines, supra note 20, at 1 . Under the "scope of legal services rendered," the Guidelines noted that "advocacy of appropriate reforms in statutes, regulations and administrative practices is a part of the traditional role of the lawyer and should be among the services afforded by the program." Guidelines supra note 20, at 7. But OLS never emphasized this point either in the enumeration of objcctives or in a separate document. Nor was there any attempt to determine roughly what proportion of the project's resources should be devoted to law reform.

79. The state bar association commissioned the Pendleton Detcctive Agency to perform an investigation. The detectives sought out clients without prior consent from their attorneys, in violation of the Canons of Ethics. A separate investigation by OEO reported that the bar's charges were "based on hearsay information and rumors that were not adequately checked by the complainant before submission." OEO, Composite Report on Investigation of Charges Made By Bar Association of the State of Mississippl Against the North Mississippi Rural Legal Services Program, 1970.

80. Evaluation teams often interviewed clients without first contacting the lawyers representing them, and asked detailed questions about their impressions of the quality of representation they received.

81. A fact of some importance was the persistent support given the Mississippi statc bar by Clark Reed, Chairman of the Mississippi Republican party. However, even members on the White House staff inclined to disregard this fact expresscd strong skepticism and suspicion of the manner in which OLS officials defended the project's activities. They complained that OLS seemed to be asking them to "take on faith" assertions that the project was operating in accord with "national policy." Morc impor. tant, they felt less justified in giving Reed an unequivocally negative response-a clear "brush-off"-in the absence of well-defined and enforced guidelines. Personal mcm. orandum of the author, Richard Blumenthal.

82. The inadequacy of the Guidelines was illustrated by attempts of OLS officinls to assess the propriety of a campaign against police brutality conducted in Albuquerque, New Mexico, by the Director of the Legal Aid Society (LAS), William Fitzpatrick. Following the shooting of a young Mexican-American, Fitzpatrick joined in picketing (carrying a sign reading "Support your local Gestapo"), endorsed a critical leaflet and testified before the Albuquerque Metropolitan Crime Commission. He defeated out. raged attempts to oust him, mobilizing the client community at one meeting to vote out a number of LAS governing board members and thus reverse the board's previous decision to fire him. See Dewey, What Happened in Albuquerque, 51 LeGA AID BRIEFCAsE $227(1970)$. Nonetheless, the dispute over the Director's actions became severely debilitating
to the project, as an evaluation reported, because of "armed war on almost every isstec between LAS and the local bar association, and the "attitude of overkill" on Fitzpatrick's part. "Political problems" were consuming "entirely too much staff time." Thomas Iikc, Evaluation Report, Jan. 14, 1970. See also Auerbach Associates Inc., Evaluation of Al. buquerque Legal Aid Society, Jan. 13, 1971. Moreover, the United Fund decided to 


\section{F. Vulnerability to Political Interference}

Many OLS officials, though aware of the potential advantages of policysetting and responsiveness, were too busy with more immediate matters or too low on the bureaucratic ladder to take responsibility for this task. A number of OLS officials, notably the two most recent directors, Terry Lenzner and Fred Speaker, tried to deal with these problems. They encountered resistance from other OEO officials, however, and from their own bureaucracy. They were further handicapped by the need to counter more basic attacks to the very existence of the program from within the Administration. ${ }^{83}$ Other OLS officials, particularly in the first years of the program, believed that there were countervailing advantages to the existing practices. Formulating, promulgating, disseminating and revising guidelines would have consumed substantial time and energy, both of which were in especially short supply during the early days of the program. Officials wanted their style to be action-oriented, a break with the usual paper-clogged bureaucratic modes. They were progeny of the New Frontier. They saw their mission as starting a large number of projects as quickly as possible, spinning out solutions to problems pragmatically, ad hoc, and free of voluminous written policies. ${ }^{84}$ Throughout recent years, as well as earlier, the absence of written policy increased OLS power over local programs, allowing OLS officials maximum discretion in dictating terms of grants and qualifications of personnel. ${ }^{85}$ Most important, however, it gave legal services a low profile. It made the program a smaller, more elusive target to attack, and permitted officials to make

cease its annual contribution which had amounted to $\$ 24,000$ in the previous year, and which constituted a significant part of the project's local share. Letter from W.D. James, President of the United Community Fund, to Board of Directors of the Legal Aid Society of Albuquerque, Dec. 10, 1969. See note $95 \mathrm{infra}$. OLS officials vere forced to remain on the sidelines. They could not reprimand or discipline the project, because the Director's activities could be interpreted as "educational" under CAP Memorandum No. 66 , and certainly did not involve the use of the mass media. But they could not defend it either, because the Director was not acting on behalf of any specific client and was clearly engaged in attempting to influence public opinion on a mass scale. See note 10 supra. Fitzpatrick's activities seemed to violate Instruction No. 6907-3, prohibiting participation in "direct action" such as picketing and parades. See note 40 supra. Iut Fitzpatrick contended that he was participating in the demonstration on his own time. Dewey, supro.

83. For a partial account of efforts by Lenzner and Speaker to deal with this problem, see notes $37,40 \& 62$ supra.

84. Interview with Bamberger, supra note 15. For a description of the attitudes of many of the founders of the antipoverty program, and the pressures under which they operated, see Blumenthal, supra note 15.

85. One Regional Director, for example, told governing boards that they must clear the hiring of any new project director with the Regional Office. Authorization for this requirement could not be found anywhere in the Guidelines, but the projects accepted it on faith. Interview with Barbara Fisher, Regional Director of OLS, Northviest Region, in Washington, D.C., Sept. 15, 1971. 
pragmatic concessions in particular instances, while refusing to make similar concessions on other projects or issues. Finally, OLS officials recognized that an absence of written policy would relieve them of the burden of facing critical arguments on the merits of issues in public forums, such as Congress, where a focus on guidelines might trigger inquiry or debate.

Whatever the advantages of this approach, the failure of policysetting and responsiveness raised the program's vulnerability to political interference by giving opponents an edge in appeals to the media or Congress, ${ }^{80}$ by fostering disputes between local projects and OLS ${ }^{87}$ and by undercutting the resources and security of program officials..$^{88}$ The time and energy that might have been invested in writing guidelines were expended instead in defending against political attack. The total pragmatism of the program and the unchecked discretion of OLS left many projects on the open seas, without cover or camouflage in times of interference. With adequate policysetting and responsiveness OLS officials might have defused many suspicions played upon by opponents-particularly suspicions about their ad hoc mode of decisionmaking. They might have forced debate to focus on the merits of policies for the nation as a whole, not on the unique defects of particular projects, which opponents were able to use to smear the entire program. Moreover, OLS and local projects might have been far more united in facing such critics, rather than bickering with one another as they did in the Dallas and Western Center episodes. ${ }^{80}$ In justifying project policies, a local official might have pointed to guidelines authorizing the challenged activity and to other projects engaging in the same activity. Perhaps most important, officials might have argued that Congress itself had tacitly approved the guidelines by declining to pass contrary legislation. Indeed, the mere existence of guidelines, apart from their merits, might have made Congress more willing to respect the independence of the program, on the theory that it was operating responsibly. The fear of congressional interference might have been thereby diminished.90 Adequate policysetting and a conception of how

86. See description of Western Center controversy, pp. 252-53 supra.

87. See description of New Orleans controversy, pp. 253.54 supra.

88. It is difficult to document this phenomenon, but the psychological effects of political interference are clearly maximized by the feeling among officials that their actions cannot be legitimated by appeal to written policies.

89. See pp. 251-52 supra.

90. The new legislation indicates that Congress may be willing to grant increasing measures of independence only if assured that policies will be formulated and disseminated in guidelines and standards. See p. 263 infra. 
power should have been allocated would have reduced the impact of interference: the concessions which many projects were forced to make, directly or indirectly, in modifying their activities; the demoralization of staff and departure of many dispirited attorneys; the tremendous drain on time, energy and financial resources; and the disillusionment of many client community members. A former OLS official described the problem. The program's policy is "assumed," he wrote, "like the air we breathe." And he commented on the costs:

The absence of written guidance gives the program an indefensibly subjective posture in the eyes of our enemies, and the failure to address ourselves to some of the really hard questions that present themselves except on a crisis basis nurtures an atmosphere of mistrust and suspicion among our supporters who are ever ready to see signs of a sellout. ${ }^{.1}$

\section{The Proposed National Corporation Legislation: Policysetting and Responsiveness}

\section{A. The Proposed Legislation and Political Interference}

The proposed legislation includes several provisions designed to reduce the vulnerability of the program to outside pressure on both national and local levels. The independence of the Corporation would be sought through the creation of an autonomous national board of directors whose members are protected from executive influence by the method of appointment and the fixed three-year term of service. ${ }^{22}$ In addition, the legislation would eliminate the provisions in the OEO Act for the governor's veto, ${ }^{03}$ a weapon used prominently against legal services projects in the past, ${ }^{04}$ and any formal relationships with state governments. Finally, the local share funding requirement would be deleted..$^{\circ 5}$

91. Memorandum, William M. Barvick, Regional Director of Legal Services, North Central Region, to Terry Lenzner, re The Need for More Written Guidance for Legal Services Programs, Jan. 20, 1970. "It is a pretty naked feeling for a staff, a director or a board to be boxed in this kind of position and to, in effect, be put in the posture of having made a broad policy decision based on subjective vicis without any written guidance for support." Id.

92. The Bill \$ 1004 (a), (b). See notes 1 \& 2 supra.

93. 42 U.S.C. $\$ 2834$ (1970). See note 18 supra.

94. See pp. $234-36$ supra.

95. 42 U.S.C. $\$ 2812(c)(1970)$. See note 19 supre. The director could waive the requirement that the grantee furnish twenty per cent of the costs of the program. but. in practice, the requirement was selectively ignored with respect to many programs which 
These provisions may protect the program against some of the more egregious attempts at political interference. The independence of the national board, for example, would discourage the kind of direct appeal to the White House or federal bureaucracy that fueled local controversy in Mississippi. ${ }^{06}$ The board would be unfettered in its choice of an executive director, possibly the most important decision to be made, and he in turn would be free of any political restrictions in considering the merits of potential employees. ${ }^{07}$ The governor's veto, though exercised infrequently, often constituted an important threat against local projects. ${ }^{08}$ The twenty per cent "local share" requirement, though often not strictly enforced by the OLS or religiously followed by projects,,$^{90}$ nonetheless forced many projects to temper their policies to meet objections from local contributors. ${ }^{100}$

Under the new legislation, however, the Corporation's independence would not be absolute by any means. A majority of national board members would owe their appointments to the President, and they might be as susceptible as commissioners of independent regulatory agencies to consultation behind the scenes. ${ }^{101}$ No limits would be set on the number of board members to be appointed from any political party, or on the number of names the President may reject on the lists submitted to him by the Clients and Project Attorneys Advisory Councils. ${ }^{102}$

failed to meet the requirement, especially where the local bar association and com. munity were considered hostile. Many grantees met the requirement almost entircly through in-kind contributions-volunteer time contributed by local attorncys, or office space provided by the city or county-the value of which could be substantially atl. justed upward. The local share was never closely scrutinized for itcmization of stich values, and the practice of "fudging" flourished. The need for meeting the local share, however, has long been regarded as a significant constraint on local programs becallse it has forced some of them to come under pressure to temper their policies in return for contributions. In Albuquerque, for example, threats of withdrawal of support from the police force caused the major source of local funds to cease its contributions. Interviews with Speaker and Johnson, supra note 15.

96. See pp. 255-56 supra.

97. The Bill $\S 1004(\mathrm{~d})$.

98. The most notable vetoes occurred with respect to projects in St. Louls and Kansas City, Missouri (Governor William Hearnes), California Rural Legal Assistance (Governor Ronald Reagan), Maricopa, Arizona (Governor Jack Williams) and Alcxandria, Louisiana (Governor John McKeithen). All such vetoes have been overriden by the Director of OEO (with the exception of the Alexandria veto) pursuant to his atithority under 42 U.S.C. \$ 2834 (1970). See note 18 supra. In addition, governors of South Dakota until 1971 informally communicated to OEO their intention to veto a grant if any was made in that state; as a result, no project was funded there during the program's first five years. Interview with Duggan, supra note 20.

99. Interviews with Lenzner, Speaker, Johnson, supra note 15.

100. See note 83 supra.

101. See, e.g., E. Cox, R. Fellmeth \& J. Schulz, "The Nader Report" on the Federal Trade Commission $134-40$ (1969); R. Fellmeth, The Interstate Commerce OMission: The Public Interest ANd THE FCC 1-9 (1970).

102. The Bill $\S 1004$. See also note 108 infra. 
As an independent corporation the program might be less likely to receive the presidential support it formerly enjoyed.103 In addition, the Corporation would still be required to obtain yearly appropriations from Congress; ${ }^{10 \pm}$ the legal services program in the past has faced a number of severe battles at this stage. ${ }^{105}$ Officials of the Corporation for Public Broadcasting, the model for the National Legal Services Corporation, ${ }^{106}$ have found this process to create "a strong perception of

103. The fervent and unswerving support which President Johnson gave to the antipoverty program as a whole was often crucial to legal services, particularly in budget fights, when spending totals for the entire OEO were at stake. See LEvrss, supra note 104. Under President Nixon the OEO was reshaped: the experimental and innovative aspects of its mission were emphasized, new personnel were appointed to key positions, and certain programs, such as Head Start and the Job Corps, were delegated and then transferred to other federal agencies. With these changes, President Nixon adopted the program as his own. Its budget was his budget, its officials were his appointees. Though his enthusiasm for OEO did not match President Johnson's, he could not simply walk away from it and be free of responsibility. Yet a President might casily abandon the new Corporation. He would be in no way responsible for its budget, its Chaiman, its activities or executive staff. Supporters of the Corporation cannot arguc for its independence and, at the same time, contend that the President must defend it as his own.

104. The Bill \$ 1009 .

105. The most widely publicized battle was over the so.called MIurphy Amendment. In December 1969, the House-Senate Conference Committee deleted an amendment added by the Senate (offered by Murphy) to the Economic Opportunity Amendments of 1969 . Act of Dec. 30, 1969, Pub. L. No. 91-177, 83 Stat. 829. The amendment would have given state governors the power to veto funding grants for legal services projects in whole or in part and would have eliminated the existing power of the Director of OEO to override the veto. 115 CoNG. REc. 29894 (1969). The board of goicrnors of the American Bar Association described the amendment as "oppressive interference with the freedom of the lawyer and the citizen' which would 'discourage actions that are politically unpopular." N.Y. Times, Oct. 29, 1969, at 46, col. 1. The Washington Post said that the amendment threatened "to kill one of the most creative and socially useful projects financed by the Office of Economic Opportunity." Washington Post, Oct. 22, 1969, at A22, col. 1. See generally S. LeVITAN, THE GREAT SocieTy's POOR LAw (1969).

106. A major ABA study recommended the corporation option as the best means of assuring "permanence" and "program stability," as well as "independence." It suggested that the "policy-making board" have a majority of lawjers, with significant representation of the judiciary and the organized bar. The corporation, modeled after the Corporation for Public Broadcasting, would have received for a permanent authorization a minimum of $\$ 90$ million. The study was completed by the Section of Individual Rights and Responsibilities and the Standing Committee On Legal Aid and Indigent Defendants in February 1971, under the staff direction of Charles Edson, former Dircctor of the Office of Operations, OLS. See ABA, SEction OF INDividual RIGITS AND REsto:SIBILITIES AND THE STANDING COMMTTEE ON LEGAL AID AND INDIGENT DEFEND.ANTS, JOINT Informational Report. The Corporation for LeGal Services $42-59$ (1971). In a resolution adopted on April 29, 197I, in Williamsburg, Virginia, the AB.'s board of governors approved in principle the concept of a corporation for Legal Services "the charter of which shall contain assurances that the independence of lawyers involved in the Legal Services program to represent clients in a manner consistent with the professional mandates shall be maintained." ABA Resolution of April 29, 1971, reprinted in Hearings on the Economic Opportunity Amendments of 1971 Before the Subcommittec on Employment, Manpower and Poverty of the Senate Commillee on Labor and Public IFelfare, 92d Cong., lst Sess., pt. 4, at 1464 (1971) [hereinafter cited as 1971 Senate Hearings].

The National Advisory Committee of the legal services program submitted a set of recommendations to the White House on March 24, 1971, endorsing the corporation concept. "The federal government must continue to shoulder the responsibility for the support and maintenance of the Legal Services Program." Its goals included "elforts to improve institutions of justice to make them more effective and efficient." The corporation recommended would have had a board of twenty-ehree members, with client 


\section{pressure,"107 whatever the justification for it in terms of the rights of the constituency Congress represents. \\ Perhaps most important, past challenges to the program's independ- ence have rarely resulted from direct presidential intervention of the}

representatives. National Advisory Committee on the Legal Services Program, Recom. mendations on Proposed Transfer, March 24, 1971.

The Citizens Advocate Center sponsored two influential studies, supporting the corporation proposal on the condition that the legislation require the "promulgation of procedures, the articulation of criteria, the delineation of the decision-making process and the creation of effective mechanisms to hold the private corporation to its own procedures and standards." Citizens Advocate Center, Legal Services: Where Next? A Discussion of Legislative Alternatives 16 (undated); Citizens Advocate Center, Legal Services: An Agenda of Current Issues (undated). The corporation, they contended, "might have relatively little leverage to affect the restructuring of the legal system" and the proposal failed to deal with "the question of discipline of members of the profession." Citizens Advocate Center, Legal Services: Where Next?, supra, at 16. The studics drew heavily on a report submitted by Edgar and Jean Cahn to the President's $A$ dvisory Council on Executive Organization. Cahn \& Cahn, Legal Services: Alternative Organiza. tional Models, June 9, 1970 . This report seriously considered transfer of the program to the judiciary, but rejected the idea because of the courts' historic "difficulty in securing funds," and "the possible jeopardy to the special but extremely precarious status which that branch now holds in the public mind." Id. at 27. Though the Cahtis themselves believed that these obstacles could be overcome, their consultations with various members of the judiciary, including the Supreme Court, persuaded them that transfer to the judiciary would be strongly opposed. Interview with Edgar Cahn, former Special Assistant to OEO Director Sargent Shriver, in Washington, D.C., Aug. 18, 1971.

Various arguments were considered by these studies in favor of alternative organizational models. The Justice Department location was seen as a means of involving more of the legal profession in the program, and of insuring maintenance of high professional standards. Citizens Advocate Center, Studies supra. However, this option involved conflict of interest problems, insofar as the agency would be responsible for representation of both sides of a case involving the government and a legal services client. Both HEW and HUD were seen as agencies with sympathies, constituencies, alld programs similar to those of OEO, but subordination of legal services within a linc department would reduce its visibility and hence its symbolic importance. Furthermore, the same problems of political interference would be possible so long as a Cabinet officer had responsibility for the program. Responsiveness to the client group would bc mini. mized, and the objectives of the program subordinated to those of the mission of the department. Id. The ABA study, like the Cahns' report, recognized the "great appeal" of locating the program in the Administrative Office of the Courts of the Judicial Branch because it would "increase public confidence in the rule of law," as well as insulate the program. ABA JOINT INFORMATIONAL REPORT, supra, at 26. But the study noted that the institutions were already overburdened by administrative duties and "non-judicial functions," and had significant "funding difficulties." Id. at 27-28. The study considered sixty governmental bodies as possible models for the independent legal services entity, categorizing them into four groups: independent agencies in the Executive Branch, government-owned corporations, private non-profit corporations which receive federal funding, and private profit-making corporations established by congressional enactment. Id. at 59-129. The above studies were made available to officials in the White Housc responsible for writing the Administration's legislative proposals, as well as to Congress. men and their staffs. Possibly the most influential document supporting the creation of a Corporation was the Report of THE PrEsident's Commission on Executive OnganizamoN, see note 4 supra. The Report recommended the establishment of such a corporation as a step toward "reprivatization" of the legal services program. It said: "While govern. ment support is still necessary the need is not as strong today. The prograin has generated considerable interest and support in the private sector ...." The reprivatization approach, implying an end to government funding, strongly set this study apart from the others cited above.

107. Interview with Macy, supra note 12. The Corporation for Public Broadcasting has come under sharp criticism for deleting or delaying programs which were considered critical of the government or of private companies that contribute funds. Sec Varicty, Oct. 13, 1971, at 21, col. 1, and N.Y. Times, Oct. 13, 1971, at 91, col. 4; id., Oct. 17, 1971, 
kind the legislation is designed to prevent. More often, intervention has come from local institutions or officials-mayors, CAA's, bar associations, and state executives-who are targets of legal services suits or whose spheres of influence in the community are challenged by advocates for the poor.

Nonetheless, the new legislation would give the Corporation a fresh opportunity and a clear mandate to take further steps to insure that the program is "free from extraneous interference and control."108 Congress has made plain its intent that legal services attorneys should "enjoy the same protection from interference" as private attorneys. ${ }^{100}$ Throughout the statute there are indications that Congress expects the Corporation to formulate more detailed and specific standards and guidelines expressing policies. For example, in addition to promulgating eligibility standards"10 the Corporation is required to "establish such procedures" as may be necessary to provide poverty lawyers and clients the same protection from interference in the attorney-client relationship as private attorneys and their clients enjoy;"11 to "establish procedures for the conduct of legal services programs assisted by the Corporation," including supervision by a goverming board; ${ }^{112}$ and to prohibit legal services attorneys from engaging in any outside law practice "unless permitted as pro bono publico activity pursuant to guidelines established by the Corporation." 113

\& 2, at 19, col. 1. "The problem is that the corporation is forced to exist in limbo between public and private spheres," Macy said, "with the perception in both places that it's really a government agency and subject to pressure." Interview with MIacy supra. The CPB depends at present on Congress for $\$ 35$ million of its $\$ 40$ million budget (1972), with the remaining $\$ 5$ million contributed privately, almost all by major corporations. Legislation has been introduced in this session of Congress to provide for appropriations by pre-determined formula every year. See H.R. 7443, 92d Cong., 2d Sess. (1971). Other arrangements are also under consideration. "Our principal task," MIacy said, "is long range financing. It's vital." Interview with $\mathrm{Macy}$, supra note 12. The New York Times recently commented editorially: "It is obvious that unless public broadeasting is funded on a regular instead of a beggar basis, both national and local producing arms will become gun-shy and avoid the major themes and concerns that the American people deserve to have aired, especially in the realm of public affairs." N.Y. Times, Oct. 20, 1971, at 46 , col. 2 .

108. The Bill $\S 1001(6)$.

109. Id. § 1006(a)(7).

110. Id. \$ $1006(\mathrm{a})(8)$.

111. Id. $\$ 1006(\mathrm{a})(7)$.

112. $I d . \$ 1006(\mathrm{~b})(6)$.

113. Id. $\$ 1006$ (d). In addition, the Corporation must specify in regulations the criterin it will apply in approving funding applications. Id. $\$ 1000(b)(4)$. Records with respect to contracts and grants must be open to the public, Id. $\S 1008(a)$, and all reports of evaluations and inspections must be available to the grantee or contractec, Id. $\$ 1008(b)$. Guidelines and regulations must be published in the Federal Register, following notice and reasonable opportunity for comment. Id. $\$ 1008(c)$. These provisions, in addition to the availability of all filos and documents to Government Accounting Office auditors, 
Although Congress' decision to delegate responsibility for policysetting and responsiveness is fundamental to the legislation, Congress may properly intervene if the Corporation fails to set such standards and guidelines. Congress would probably be more inclined to defer to a Corporation which defines and enforces policies and develops formulae for allocating control to the competing constituencies. To a large extent then, the independence of the Corporation would depend on its competence-and on its appearance of competence-in policysetting and responsiveness. ${ }^{114}$ The lack of such competence would pro.

Id. $\S 1010$, should substantially tighten the administrative, record-keeping, and management aspects of the program.

In addition, the bill would give projects certain procedural rights in case OLS denics refunding, which now exist only if a project is officially terminated in the midst of the program year. Applications for renewal of financial assistance would not be rejected, under the bill, unless OLS provided "reasonable notice and opportunity for timcly, full and fair hearing." The Bill $\$ 1014(2)$. At present, in case of denial of refunding, OLS must afford a project only "reasonable notice and opportunity to show cause why such action should not be taken." 42 U.S.C. \$ 2944(2); 45 C.F.R. \& 1067.2 (1971). Only in case of termination is a hearing currently required. 42 U.S.C. \& 2944(3) (1970); 45 C.F.R. $\$ 1067.1$. A "full and fair hearing" would almost certainly mean that projects would be guaranteed a formal, recorded proceeding, with opportunity to participate in questioning officials and access to official evaluations. The procedure presently applicd in refunding denials increases the power and discretion of the OLS. This procedure-and the problems it raises - are illustrated by the OLS decision to merge (and thereby deny refunding to) the Monmouth County Legal Services Organization in New Jersey (MILSO) with the neighboring Ocean County Legal Services Project. A strongly critical cvaluation of MLSO indicated that there was "little or no law reform"; the bar dominated the governing board (by appointing nine of its seventeen members); and all controversial cases had to be cleared in advance with the project director. Aucrbach Associates Inc. Evaluation Report, Monmouth County Legal Services Program, New Jersey, Oct. 29, 1970. Prior to the merger, OLS offered the project an opportunity to submit written materials and attend an "informal meeting." Letter from Ronald Dictrich, Acting Dep: uty Director of OLS, to Lawrence C. Stamelman, Chairman, Monmouth County Legal Services Organization, Dec. 16, 1970. The merger decision was explained on the grounds that the program was "severely deficient" and that a "merged program" would be capable of "increased specialization" and more effective "recruiting of calented lawyers." Letter from Dietrich to Stamelman, Feb. 24, 1971. Filing stit against OEO officials, the project requested a preliminary injunction against the merger, on the grounds that OLS refusal of a formal hearing denied them due process. Judge Lacey declined to grant the injunction, but he sharply criticized the "cavalier handling" by OLS of the project and the "flagrant disregard of its own regulations." Monmouth County Legal Services Organization v. Frank Carlucci, Civil No. 1137-71 (D.N.J. Aug. 31, 1971). He pointed to the refusal of OLS to give the project a copy of the Auerbach Evaluation, its fallure to discuss other sources of information on which it relied for its merger decision (including extensive consultation with the New Jersey Department of Community Affairs), and the refusal of leading OLS officials to testify and present written evidence in the procecding. $I d$. The OLS officials, noted Judge Lacey, seemed to be claiming "absolute, unchecked and unreviewable discretion," and had shown "their own lack of respect" for the lcgal system. Id. Nonetheless, he felt "constrained to hold that technically the OEO action was a denial of refunding and not a termination and, accordingly, that OEO acted in conformity with appropriate statutory and regulatory provisions." Id. Although Lacey's comments struck a common cause of resentment on the part of many projects, oLs officials thought the criticism to be unfair (while welcoming the holding). Intervicw with P. Vaughn Gearan, Regional Director of OLS, Region Two, in Washington, D.C., Sept.
16, 1971.

114. See note 90 supra. 
vide critics with a ready rationale to challenge the justification for the Corporation's autonomy.

There are two primary reasons for which Congress should be concerned with policysetting. The first is the necessity for choice resulting from the scarcity of government funding. Under foreseeable levels of appropriations, the government will not even come close to allocating sufficient funds to provide lawyers for all who need legal services. ${ }^{115}$ As long as demand outruns supply the program will be forced to allocate its services among those in need.110 There will thus be a need to formulate rationing policies which express the program's priorities and a notion of procedural fairness. Without a policy, rationing will at best be accomplished by queuing; at worst it will become arbitrary. Adequate policysetting assures that priorities, when formulated, will be effected in practice, and that there will be a certain minimum consistency and fairness of operation whereby individuals in like situations will be dealt with alike.

The second reason for the importance of policysetting is the necessity for delegation of authority. A considerable amount of discretion and policymaking responsibility on major issues will be given to those who administer local programs. Delineating responsibility thus becomes vital. The Corporation must make clear which decisions or which parts of a decision are delegated, and to whom the responsibility is assigned at the local level. ${ }^{117}$

115. At a funding level of approximately $\$ 60$ million for fiscal year 1971 , it vias estimated that "four out of every five legal problems of the poor go unattended." President Nixon, Message to Congress, supra note 1. The program served approximately eighteen per cent of the "universe of need" for legal assistance in 1970, according to Frank Carlucci, then Director of the Office of Economic Opportunity, 1971 Senate Hearings, supra note $106, \mathrm{pt}$. 1 , at 145.

116. A distinction should be made between those who need legal services and those who express that need, since only a portion of those who have legal problems will actually come into a neighborhood law office. The high caseloads of legal services attorneys and the necessity in many projects of rejecting on other grounds individuals who are financially eligible, however, attest to the inability of supply to kecp up cren with expressed demand.

117. The confusion on this issue is illustrated by the President's Veto Statement. The president argued that the "sole interest" of each board member must be the "public interest," and "the sole constituency he must represent is the whole Ameriean people." Therefore, he argued, the board members should be appointed by "the one official accountable to, and answerable to the whole American people," the President, and he should be given a "free hand" subject to the advice and consent of the Senate. But, in apparent contradiction, the President also contended that the Legal Services Corporation must place "the needs of low income clients first, before political concerns of cither legal services attorneys or elected officials." The President's Alessage to the Senate Returning S.2007 without His Approval, supra note 2. A number of Congressmen disputed the President's argument. In a supplemental comment on H.R. 12350, added to the Report of the House Committee on Education and Labor, seven members of the President's party said: "The need for independence is clear-but there is need for accountability as well. Members of this Committee, both in hearings and in the Conference 


\section{B. Responsiveness: The Allocation of Power}

A normative analysis of responsiveness will provide criteria for assessing the claims of constituencies; for distinguishing legitimate claims from illegitimate ones, and thereby identifying political interference. The Corporation may use criteria other than those suggested below, but it must define some criteria by which to allocate political control among the various competing constituencies.

The determination of appropriate degrees of control should depend on two criteria: the impact of the program on members of the constituency, i.e., its effect on their lives or their interests, and the contributions which the members of the constituency may make to the program in terms of resources and expertise. Other criteria, some of them incompatible with impact and contributions, are available but embody substantial defects. ${ }^{118}$

Committee from both sides of the aisle, struggled with the problem of accountability in attempting to insure that the Corporation would be responsive to the Congress, the Executive Branch, professional considerations and the Bar, as well as respond to the primary concern of the client representation. . . . In our view the present Title $X$ creates a Corporation more accountable to these various interests than cither the original bi-partisan or Administration bills." H.R. Doc. No. 355, 92d Cong., 2d Sess. 74 (1972) Representative Carl Perkins, Chairman of the Committee, commented during the House debate on the legislation: "Congress too is concerned with accountability and the nced to create a corporate entity that would be responsive...."118 Conc. REC. H1061 (daily ed. Feb. 16, 1972). But Representative Quie countered: "The only way one call get accountability is for the President to have a free hand to appoint the members of the board ...." 118 Cong. REc. H1213 (daily ed. Feb. 17, 1972).

118. Perhaps the major alternative would be a criterion of representativeness, re. quiring the degree of responsiveness to a particular constituency to depend only on the number of members it has, relative to the others. This criterion fails to take into account the very great differences of impact which the program may have on the lives of different types of constituents, and would in practice allow the poor little control over decisions which affect their lives.

Other criteria, such as political power, have more serious deficiencies. The argument for the criterion of political power would be that the public good is best determined by a kind of free market interplay of different interest groups, whose power may not be proportional to numerical strength, and that the claims of constituencies to respon. siveness should be judged in accordance with the pressure they are able to bring to bear through specified channels (e.g., through elected officials) in the political proccss. This criterion, however, would cloud the distinction between responsiveness and political interference, even if pressure were confined to certain channels of expression, and the program would soon become captive to the special interests of the most powerful groups, many of them contrary to the interests of the poor or the community-at-large.

Another possible criterion would be adverseness of interest, or opposition to the pro. gram. This criterion would differ from the one of "impact" recommended by this Note in taking account only of potential or actual damage to a constituency's interests, and excluding consideration of any beneficial or positive effects it might have. It would makc the program responsive mostly to those it threatens. The rationale for this criterion would be that a program with so great a tendency to hurt certain groups (private lawyers, or opponents of legal services clients), or which encounters so much opposition from those groups, should accord them a higher degree of responsiveness. If the com. plaints of opponents were answered and their hostility eased, the program might also bc more effective. The price of such involvement, however, is likely to be a compromisc of vital goals and interests at the expense of those served.

A variant of the political power criterion is responsiveness to a single elected official, 
The use of impact as a criterion is supported by the principle that individuals ought to have a degree of control over the institutions which affect their lives, and that a program which has very different effects on different constituencies ought to be most responsive to those on whom its effects are greatest. This analysis is supported by the guiding principle of the federal antipoverty program, the "maximum feasible participation" of the poor. ${ }^{110}$ The use of this criterion also aids the legal services program in achieving one of its most important objectives: changing the attitudes of the poor toward their own lives, the legal process and the institutions of society. A program which does things for or to the poor without their control, in the manner of the old social services programs, is likely to have a smaller effect on their attitudes than one which involves them in the essential decisionmaking of the program. ${ }^{120}$

The criterion of contribution would enable the program to take account of potential inputs of resources, expertise and information from the various constituencies in allocating degrees of participation and control among them. Responsiveness to these constituencies provides an incentive or reward for their contributions, and also a means by which such contributions may be delivered.

Political interference, by this analysis, is a claim to excessive control over legal services projects-a claim that is not warranted by the pro-

such as the President. Such a criterion might have the virtue of simplicity, And would give one democratically selected individual responsibility for deciding the merits of constituencies' claims. But it would most likely amount to much the same system as now exists, with most of the same deficiencies. In any event, this criterion would be clearly contrary to the legislative intent that the poor should participate in decisionmaking. see note 119 infra, and would possess the same deficiencies as the criterion of political power.

119. 42 U.S.C. $\S 2791(f)(1)(1970)$. This section provides that Community Action Agency boards should facilitate "maximum feasible participation of residents of the areas and members of the groups served, so as to best stimulate and take full adiantage of capabilities for self-advancement and assure that those programs and projects are otherwise meaningful to and widely utilized by their intended beneficiaries." According to 42 U.S.C. $\$ 2791(\mathrm{~b})$, a CAA board must be composed of "at least one third ... persons chosen in accordance with democratic selection procedures adequate to assure that they are representative of the poor in the area served." Of the members, the total number of which cannot exceed fifty-one, one-third must be "public officials" (unless they are unwilling to serve), and the remainder are to be "officials or members of business, industry, labor, religious, welfare, education or other major groups and interests in the community." These provisions were added in the Economic Opportunity Amendments of 1967. Act of Dec. 23, 1967, Pub. L. No. 90-222, 81 Stat. 672 (codified at 42 US.C. $\$ 2809$ (1970)). However, the phrase "maximum feasible participation" was used in the legislation first passed by Congress, the Economic Opportunity Act of 1964, defining a Community Action Program as a program "which is developed, conducted and administered with the maximum feasible participation of residents of areas and members of the groups served . ..." Act of Aug. 20, 1964, Pub. L. No. 88-452, \& 203(3)(3), 78 Stat. 58 (codified at 42 U.S.C. $\$ 2791(f)(1)(1970)$ ).

120. See Cahn \& Cahn, supra note 14. See also Cahn \&: Cahn, What Price Justice: The Civilian Perspective Revisited, 41 Notre Daxe L. REv. 927 (1966). 
gram's impact on a constituency or the constituency's contribution to the program. By contrast, proper intervention consists of claims which are warranted by impact and contribution and which do not violate other particular values, constitutional prohibitions or ethical restrictions such as the attorney-client relationship. A claim might relate to the structure of an institution, for example a general claim to greater representation on the governing board or control over the funds received by the delegate project. Or it might relate to eligibility or services, for example, a claim on a particular issue asking for a change in policy. The legitimacy of a particular constituency's claim will vary from issue to issue. Furthermore, the criteria of impact and contribution will often conflict. The client community may be the most affected by a decision, while the bar may have the most expertise. When this occurs, the competing claims must be balanced against one another. It cannot be pretended that an analysis of impact and contributions will yield precise solutions. An analysis of the problem based on those two considerations, however, will be sufficiently sensitive to guide the kinds of decisions necessary for the allocation of decisionmaking power and responsibility within the program.

\section{G. Proper Degrees of Responsiveness: Comparing the Constituencies}

Applying this analysis, the Corporation should stipulate in general terms how control over the program should be allocated among the four major constituencies: the community at large, the professional community, the client community and the legal services attorneys.

1. The community at large has a significant claim to be represented at the national level of government, arising from its contribution of tax revenues for the program's operation. In the case of any other public program, this contribution would justify virtually any legislative evaluation, alteration or reform. But in the case of legal services, Congress has explicitly indicated its intent to defer to the Corporation on day-to-day or even year-to-year decisions. Such deference is implied in the Corporation's mandate for independence. ${ }^{121}$ Without some measure of deference, the Corporation's much-heralded autonomy would be meaningless. ${ }^{122}$ Yet the fact that the Corporation will have to seek yearly appropriations from Congress suggests that a degree of repre-

121. See p. 264 supra.

122. Of course, any attempt to influence the handling of a particular case which has been accepted by a legal services attorncy would be presumed to violate the attorney. client relationship. 
sentation of the community at large will take place, though this may be limited to occasional long-range policy review.

The role of Congress at the national level would be sufficient to satisfy claims based on the contribution of the community at large. At the local level, this constituency's contributions have been negligible in terms of funds and expertise. ${ }^{123}$ Contributions at the national level do not justify additional claims to responsiveness made at the local level by a mayor, governor, or other public official.

At both the national and local levels, the impact of the program upon the community at large is more diffuse than upon the client community. Particular law reform cases, such as school desegregation suits or challenges to the welfare department, may accelerate long run social change or contribute to tax increases in the short run. But these may be the effects of a variety of phenomena, only one of which may be litigation by legal services projects. The claims of the community at large deriving from the program's impact would seem to be answered by the congressional decision to create an independent Corporation, and Congress' continuing prerogative to periodically review its general operations. These claims do not justify the ad hoc influence which many public officials have sought to exercise in the past.124

2. The claim of the organized bar derives primarily from the impact of the program on the livelihoods of lawyers, resulting from competition with legal services attorneys who can offer their services for free because they are subsidized by the government. The number of clients actually drawn away from private counsel who are capable of paying for the particular service sought has never been measured. It is likely that legal services projects have served some clients who could have stretched their financial means to afford private counsel for some kinds of services. ${ }^{125}$ But since eligibility requirements were keyed,

123. Interview with Duggan, supra note 20. Interview with Speaker, supra note 15. If the local share requirement were eliminated, as would be anticipated under the Bill, these contributions could be expected to drop even further, as local projects viould not solicit them as energetically to make up the twenty per cent share.

124. See note 83 supra.

125. There is some evidence that the competitive impact of the program may be borne in large measure by black attorneys practicing in poor communities. A prominent black lawyer and publisher from San Francisco recently told a congressional committec that he favored a "judicare" program, with payments to private lawyers for service to poor clients, because: "The black law firms consistently dry up because no matter what you say, you are taking away from these black law firms our clientele so that vie don't have an opportunity to develop a spawning ground for young lawyers to come in, and if they came in, we would not be in a position to pay them because you are taking money out of the community ...." Testimony of Thomas Berklcy at Hearings on Oversight into Administration of the Economic Opportunity Act of $196 \mathrm{f}$ Before the Special Hearing Subcommittee No. 2 of the House Commitlee on Education and Labor, 92d Cong., Ist Sess. 174-214 (1971). 
inter alia, to low income and a refusal by private attorneys to accept a case, one must suspect that the number of clients actually taken from the private bar has been relatively small. ${ }^{126}$

The bar has generally been assumed to make a contribution of expertise, through its governing board members, that guards against any dilution of professional standards in the operation of the program. But this supposed contribution rests on a very suspect assumption: that the professional conduct of legal services lawyers should be subject to a special form of professional oversight or scrutiny not applied to private practitioners. There is no reason to expect that the standards embodied in the Canons of Ethics and the Code of Professional Responsibility and enforced by local bar associations will provide insufficient protection against improper conduct by legal services attorneys. No extra mechanisms, such as "watchdog" representation on governing boards, are required. Indeed, to the extent that such demands for special scrutiny are motivated by a general hostility to legal services from certain elements of the bar, evaluations of projects by teams of individuals, including lawyers, from outside the community may provide more impartial and penetrating criticisms and suggestions for upgrading quality.

The private bar has also made some contribution of time by representing clients in simple matters and advising less-experienced project attorneys. These services have been counted as an "in-kind" portion of the twenty per cent local share required for OEO funding grants. But the extent of such volunteering has never been more than marginally significant to the program, and the local share requirement would be eliminated in the Corporation legislation. ${ }^{127}$ Furthermore, whatever claim to responsiveness may be derived from volunteer services is a claim that belongs to a relatively small number of lawyers who may not identify with the leadership of the organized bar. The claims of the bar, though real, thus warrant less extensive control over legal services than that constituency has exercised in the past. ${ }^{128}$

126. Although statistics have never been compiled, project directors rarcly rely heavily on volunteer manpower, since it is unpredictable in both quantity and quality. Particularly for important law reform cases, which may require full-time attention from a staff attorney, they tend to depend on their own staff. Such volunteer timc has becn significant only because projects were able to count hours spent by voluntecr attorncys as contributions toward the local share at rates which the volunteer attorneys normally would have billed clients. Interview with Dugan, supra note 77. Interview with Paul Newman, Regional Director of OLS, Northeast Region, in Washington, D.C., Sept. 16, 1971.

127. See note 95 supra.

128. See pp. 247-50 supra. 
3. The main impact of the legal services program is on members of the client community. Clients have a tremendous stake in decisions as to who gets services, what types of services will be available, which problems will get priority, which resources will be devoted to law reform, and which community groups will be represented. The impact of such decisions is palpable and direct for the poor, particularly when limitations on resources compel choices among recipients of the service.

The poor also make significant contributions to the program. They may bring to policymaking bodies knowledge of community problems that is unavailable from other sources. In addition, they can provide links between project attorneys and neighborhood residents through effective canvassing and organization (outreach) and can mobilize support for the program when it is under attack. Though legal services attorneys may sometimes advance the interests of the client community, representatives of this constituency should be primarily people eligible for legal services. ${ }^{129}$ Clients seem to have been underrepresented in the past, for a consideration of the impact of the program on them and their potential contribution to the program suggests that the client community should receive the greatest degree of control afforded to any single constituency.

4. Although they are employees of the program, legal services attorneys also have a strong claim to participation in its governance. Their status differs from that of partners in a private law firm primarily because of the fact of government funding. Yet each grantee project has many of the characteristics of a law partnership, and the source of funding should not totally disqualify legal services attorneys from participation in their project's decision-making. The program has an important impact on their lives, not merely because their personal incomes depend on it, but because they are the ones who must carry out decisions of policy, and their professional careers are often at stake. Aside from their normal service to clients at relatively low salaries, they contribute invaluable expertise to governing boards, much overtime for which they are never paid, and they volunteer assistance to community organizations. Unresponsiveness to this constituency might result in a diminution or disappearance of many of these contributions and perhaps a large number of resignations as well. ${ }^{130}$

129. See notes $10 \& 49$ supra.

130. The above discussion is based on the assumption that legal services will continue to involve grants to projects with full-time staff attorneys. An alternative supported by 


\section{Options for the Legal Services Corporation}

\section{A. Policies in the Legislation}

Though there is abundant evidence of a congressional desire for policysetting and standards of responsiveness, ${ }^{131}$ the proposed legislation would impose few specific policies on the Corporation. The composition and method of selection of the Corporation's board of directors is described in detail, heavily weighting the balance of power in favor of the community at large and the professional community. ${ }^{132}$ But only a few of the Corporation's responsibilities are specified (the appointment of the director being one), and the division of authority to be

many bar members would be adoption of a judicare approach to the funding and delivery of services. A judicare approach would involve government payments directly to private attorneys for providing representation to certified poor clients, much as the Medicare program now operates. It has been argued that such an approach would reduce the possibility of interference because it would bring all representation decisions under the protection of the attorney-client relationship. See Preloznik, Wisconsin Judicare, 70 W. VA. L. REv. 326, 328 (1968). In addition it would eliminate the very visible (and vulnerable) legal services bureaucracy, and create greater incentives among the privatc bar for the expansion of funding for legal services. Studies of initial experiments, how. ever, have indicated that judicare programs have higher average costs per casc than most projects and virtually no law reform activity. John D. Kettelle Corporation, Evalu. ation of Wisconsin Judicare, September, 1970. "Judicare has known little litigation outside of domestic relations, bankruptcies, and terminations of joint tenancy . . . " Id. See also Robb, Alternate Legal Assistance Plans, 14 Catrouc Xawyen 127 (1968). Masotti and Corsi, Legal Assistance for the Poor: An Analysis and Evaluation of 'Tt'o Programs, 44 J. URBan L. 483 (1967).

131. See note 113 supra.

132. The Bill $\S 1004(a)$. The Corporation Board of Directors would be appointed by the President, with the consent of the Senate. One board member would be elected annually by the board to serve as chairman. Six of the members would be appointed from the "general public," though at least three of them would have to be attorneys. Two members would be selected from lists of nominees submitted by the Juclicial Conference of the United States, and five members (one per list) from lists submitted by the following organizations: the American Bar Association, the American Trial Lawyers Association, the National Bar Association, the National Legal Aid and De. fender Organization, and the Association of American Law Schools. Two members would be appointed from among individuals eligible for services from lists submitted by the Clients Advisory Council. Finally, two members would be former legal services attorneys, chosen from lists submitted by the Project Attorneys Advisory Council. Each initial list, and any subsequent list submitted at the President's request, would include not less than three nor more than ten names for each position. It is thus certain that a majority of the members will be appointed from the professional community, since the President must appoint a minimum of ten from that constituency, apart from attorncys who are former employees of legal services projects. The President, representing the community at large, has substantial discretion in selecting members, since he may reject all the names on a list submitted by any of the nominating groups, and there is no limit on the number of new lists he may request. In effect, the legislation gives the community at large the power to pick a controlling majority composed of professional community representatives, as well as those of their own constituency. Moreover, the fact that the l'roject Attorneys Council may nominate only former employees of projects means that legal services attorneys would be given only indirect representation. 
made between the Corporation and its grantees is nowhere defined. ${ }^{133}$
The bill would also establish two eleven-member advisory councils,

133. There is the additional problem of how the Iegal services provided by the Corporation should be related to existing programs of legal services funded by the Departinent of Housing and Urban Development and the Department of Health, Education and Welfare. Such programs outside OEO involved expenditures of roughly $\$ 7$ million in fiscal year 1970, barely ten per cent of the $\$ 60$ million OEO legal services budget, but funding might well be expanded by these Departments on competing or complementary projects. The Bill would authorize the Corporation to "offer advice and assistance" to all federal programs, which would include "reviewing all grants and contracts" for the provision of legal services and "making recommendations to the appropriatc federal agency." The Bill $\S 1006(a)(6)$. It would also include "revieving and making recommendations to the President and Congress concerning any proposal" for Iegal services. Id. The Corporation would also be authorized, upon request of the President, to provide "training, technical assistance, monitoring and craluation services to any federally assisted legal services program." Id.

Through its Model Cities Program, HUD has funded legal services in thirty-cight cities, with an expenditure of $\$ 4.2$ million in fiscal year 1971. NAT'L J., April 24, 1971, at 899 . The decision to use funds for this purpose belongs to the City Demonstration Agency, which is the official recipient of the federal grant. See Demonstration Citics and Metropolitan Development Act of 1966, 42 US.C. $\S 3301$ et seg. But HUD has encouraged these local agencies to support legal services since late 1968. HUD Policy Memorandum No. 21, from Walter Farr, Jr., Model Cities Administrator, to all CD. Directors, re Utilization of Legal Services Resources in Mlodel Cities Programs, December 18, 1968. HUD has generally been more willing than OLS to accept restrictions imposed on the operation of legal services. Some projects, for example, have been prohibited by City Demonstration Agencies from suing loal governments. Alemorandum from Jason Newman, Special Counsel, OLS, to Frank Jones, July 24, 1970. At least one OLS Regional Director has complained that the OLS position "is being seriously undermined by the willingness of the Model Cities program to make its funds available" to programs which OLS is attempting to free from restrictions. Memorandum from Maurice Finkelstein, Regional Director of OLS, Middle-Atlantic Region, to Frank Jones, re Charlottc North Carolina Legal Services Program-Relationship with the Mlodel Cities Ageney, March 23, 1970.

The Department of Health, Education and Welfare has funded legal services in two forms: first, a group of experimental or pilot programs under the authority of the Social Security Act, 42 U.S.C. \$ 1315 (1970), and second, state-vide programs in support of services provided to welfare recipients under 45 C.F.R. $\$ \$ 220.51$ (c)(4), 220.04(b), 22259 , 222.91 (1971). Funding of experimental and demonstration projects has been at an annual rate of approximately \$1.I million. Interview with Herbert Kaplow, Community Services Administration, Department of Health, Education and Welfare, by telephone, Sept. 17, 1971. Many judicare experiments have been tried; none has been coordinated with legal services projects. Funding for state-wide programs vas estimated at $\$ 3$ million for fiscal year 1971. Id. Only three states now have such programs-Pennsylvania, Mary. land and Georgia-but the congressional appropriation is open-ended under the current law, so that the federal govermment is obligated to provide seventy-five per cent of the funding for any state-wide program funded twenty-five per cent with state moncy. States are strongly encouraged to initiate such programs by State Ietter No. 1053, from Mary E. Switzer, Administrator, Social and Rehabilitation Service, Department of Health, Education and Welfare, to State Agencies Administering Approved Public Assistance Plans, Nov. 8, 1968.

The powers of the Corporation over the HEW and HUD programs are far narrower in scope than proponents of the Corporation idea first hoped. The Corporation's re. sponsibilities with respect to these programs are confined primarily to review and consultation. The original proponents of the Corporation wanted it to have the pover to take over the HEW and HUD efforts. In the first proposal for an independent legal services entity, a subcommittee of the National Advisory Committee chaired by former director Earl Johnson recommended the creation of a National Justice Foun. dation with the power to assume "full responsibility for the administration of" all other legal services funded by the federal government. Legislative Subeommittce. The National Advisory Committee, A Proposal for the Establishment of a National Justice Foundation, March 24, 1969, $\$ 201(a)$. One of the major objectives of the Foundation would have been to prevent competition among federally funded legal services programs, 
one for clients and the other for project attorneys. ${ }^{134}$ Their only specified responsibility would be to suggest to the President possible nom. inees to the national board as representatives of these two constituencies. ${ }^{135}$

The bill would formalize for the first time the existence of local governing boards, but would provide only a very general mandate as to their composition and responsibilities. It states merely that the boards must be "policymaking," that a majority of their members must be lawyers, and that at least one third of their members must be "members of the client community." 136 The bill does not outline the role and responsibilities of local bar associations in any greater detail than did the previous legislation, leaving the Corporation broad administrative discretion. It would eliminate the requirement that the director insure that state and local bar associations be "consulted" prior to project funding. ${ }^{137}$ Instead, the Corporation would be required merely to "notify the state bar association ... a at a reasonable time prior to the Corporation's approval" of any grant. ${ }^{138}$ The bill would also presage a fundamental change in the role of CAA's and their relationship to legal services projects. For the first time in its history, the legal services program would be independent of Community Action. Nowhere in the

to halt proliferation of staff, and to insure comprchensive planning. Letter from Johnson to Representative William Steiger, March 12, 1969; Letter from Johnson to the author, Nov. 30, 1971. The support of the $A B A$ was sought with the argument that there was a need to "consolidate all legal services programs in a new independent agency in which the organized bar would have a significant voice." Letter from Jerome Shestack, member, the NAC Legislative Subcommittee, to Bert Early, Executive Dircetor, $\mathrm{ABA}$, Feb. 13, 1969. The reduction in the Corporation's proposed powers over non.OEO legal services programs apparently resulted from a political calculation on the part of the bi-partisan coalition that a "takeover" of all federal programs would provoke oppo. sition from the departments and necessitate broader legislation, thereby complicating and jeopardizing the creation of the Corporation. Interview with Michacl Kantor, former Assistant to the Director of OLS, in Washington, D.C., Aug. 25, 1971.

134. The Clients Advisory Council would be selected from among "individuals cligible for assistance," while the Project Attorneys Advisory Council would consist of lawyers "who are actively engaged in providing legal services." The former would "advise" the board and executive director on "policy matters relating to the needs of the client community," in addition to acting as "liaison" between the client community and legal services programs. The latter would "advise" on "policy matters relating to the furnish. ing of legal services." Both would have responsibility, in addition, for stibmitting lists of nominees for appointment by the President to the board of directors. For details of the appointment process, see note 132 supra. The board of directors itself would be authorized to fix the procedures and method of selection of the Advisory Councils, as well as the terms of office and qualifications. For both Councils, such proccdures would "insure that all areas of the country and significant segments" of each constituency were represented. In no event could more than one representative on a Council be from any one state. The Bill § $1005(\mathrm{a}),(\mathrm{b})$.

135. Id. \& 1005 .

136. Id. \$1006(b)(6).

137. 42 U.S.C. $\$ 2809(3)(1970)$.

138. The Bill § $1006(\mathrm{~h})$. 
proposed legislation is Community Action mentioned, and the autonomy of the Corporation would remove any presumption that projects would be funded as delegate agencies of local CAA's.130

With respect to eligibility, the Corporation would be authorized to establish standards providing "priority for members of the client community whose means are least adequate to obtain private legal services."140 No definitions are provided, however, for "means" or "priority."141

With regard to services, the language and history of the legislation indicate a general intent to encourage provision of a spectrum of services as broad as that available through private lawyers. ${ }^{142}$ There appears to be a presumption that services are permissible unless specifically restricted, as are criminal representation ${ }^{143}$ and lobbying, ${ }^{144}$ but the legislation would establish no priorities among permissible services.

\section{B. Policy Options and Recommendations}

\section{Guidance and Supervision of the Program}

a. The National Corporation. The legislation would give the professional community and the community at large a degree of representation that is not warranted under the impact-contribution

139. Indeed, there are strong reasons for reversing this presumption and funding legal services projects directly. See pp. 249.50 supra. If the projects continue to be delegates, the type of interference which has plagued many programs in the past may become a more significant problem under revenue sharing plans such as the one presented by President Nixon. See The President's Address to the Nation, supra note 14. Under revenue sharing, the CAA's would become beholden to local governments for all funds which have now come directly from OEO, and would have to "compete" with other local private and public agencies for such funds. Micmorandum from Frank Carlucci, Director of OEO, to all CAA Board Chairmen, Feb. 13, 1971. Dependent on the favor of local officials for their funding, CAA's vould therefore have an cien stronger incentive to discourage their delegate legal services projects from undertaking controversial suits, particularly those which challenged practices or policies of the local government.

140. Id. $\$ 1006(\mathrm{a})(8)$.

141. The Bill has no provision on group representation, but the Senate Report states: "Client as used in this act can mean an individual or a group. The Committec has specifically found that there is a substantial need for the representation of groups and that such representation can be very effective in redressing problems in the client community." SENATE REPORT, supra note 1, at 36.

142. See generally HOUSE REPORT and SENATE REPORT, supra note 1.

143. The Bill $\S 1006(i)$. There would be a blanket prohibition on provision of services "with respect to any criminal proceedings," eliminating the flexibility in the present statute.

144. The Bill $\$ 1006(e)$. Legal Services attorneys would be forbidden to lobby unless they were either representing a client or responding to a "request" for such "representation" from a legislator, and would be forbidden to engage in any "campaign of advertising" using the media, and certain forms of direct action such as rallying or picketing. 
analysis suggested above. On the seventeen-member board these two constituencies together would have thirteen representatives, with the bar accounting for a minimum of ten, as compared to the two representatives each allotted to the client community and legal services attorneys. A partial redress of this imbalance may be achieved by the President if he appoints four or five of the "public members" to be, in effect, representatives of the poor. Such individuals might include officials of national organizations identified with the poor, lawyers who have been closely identified with the program for some time or actual members of the client community.

More important than the number or percentage of client community members on the board, however, may be the quality of their performance. They begin with a number of substantial disadvantages similar to the handicaps encountered by client community members of local boards in the past. They will lack the organizational strength and lobbying power of national professional organizations and the valuable status of being recognized "spokesmen" for their constituency. ${ }^{145}$ They will lack experience with administrative and accounting procedures used to operate a large corporation and will be more likely than other members to be inhibited by the august setting and tone of the meetings.

Special measures may be desirable to compensate for these disadvantages. Additional funds and energy should be devoted to building the National Clients Council as an organization with spokesmen and grassroots strength. Special preparation should be provided for client community representatives, possibly through informal consultation between the Corporation staff and representatives of the poor. These board members might be encouraged to take a particularly active role in the selection of the chairman of the board and the executive director of the Corporation and in the appointments of chairmen of standing committees of the board.

As an official instrument of representation, the Clients Advisory Council should be given a clearly defined role-consultative, at a minimum -with respect to the operation of the program, including budget, evaluation and staff. The decision of Congress to establish a separate

145. The heads of organizations of the poor, such as the National Welfare Rights Organization or the National Clients Council, are often challenged on the grounds that (i) their groups represent only a small segment of the low-income population, (ii) the feelings of the segment represented may be different from those of many other low. income individuals, and (iii) not even the individuals they claim to represent have any direct role in choosing leaders of the organizations. Intervicw with Hamilton, supra note 45. 
entity to represent the client community, with a specified role in the selection of board members, is ample justification for giving the Council broad oversight and investigative powers. ${ }^{140}$ The Council might be allotted a portion of the budget for evaluation purposes, to commission special assessments of projects by teams of specialists or by members of the Council themselves. It might be allotted, as well, a part of the research and development budget, to initiate experiments with particular modes of legal services delivery or particular types of clients. Its role might be viewed as a sort of legal services ombudsman, possibly even with some staff of its own. One of its responsibilities might be to establish advisory councils at the local level in cooperation with the National Clients Council ${ }^{147}$ and build them into a network by serving as a central point of communications and coordination.

b. Local Governing Boards. One of the Corporation's major tasks, as suggested by this Note's impact-contribution analysis, would be to realign the balance of representation and influence on local boards to accord greater control to the client community and legal services attorneys. Under the legislation, two major approaches would be open to the Corporation. First, the Corporation might require nothing more than the statutory minima, fifty-one per cent attorneys and thirty-three per cent members of the client community, and leave apportionment of the remainder of seats to the governing boards themselves. As a second approach, the Corporation might set affirmative representation requirements supplementing those in the legislation. One variation of this second approach would be to fix one or more of the minima as a maximum: setting the percentage of attorneys on the board, for example, at a maximum of fifty-one per cent. Another variation would be to set one of the minima at a higher level than required by the legislation. The Corporation might stipulate, for example, that forty-five per cent of the board members must be from the client community and that project attorneys have at least one representative on the board.

The aim of increasing the influence of the client community and legal services attorneys would be best served by the second and third options-the first would permit or even encourage the professional community and the community at large to consolidate and enlarge their dominance. The second option should be adopted to limit repre-

146. Though the legislation would not specify any responsibilities for the Advisory Councils in addition to their involvement in selection of board members, the recognition of the need for structured participation of client community members in this process implies a justification for involvement in other areas. See note 134 supra.

147. See p. 245 and note 50 supra. 
sentation of the professional community, whose claims to responsiveness could certainly be served by less than a majority of board membership if the legislation did not require it. In addition, a higher minimum should be set for the client community, as exemplified by the third option. Even with this combination of the second and third options, attorneys would constitute the majority on governing boards. But the disproportionate strength of the bar on local governing boards might be somewhat reduced if the Corporation provided that a certain percentage of the attorney members be legal services attorneys from the project's staff.

Also critical to the composition of the local boards will be the method of selection adopted. Though a significant degree of latitude might be allowed among forms of election and appointment, certain practices should be definitely forbidden, such as a board appointing its successors (or perpetuating itself indefinitely), or a private group (e.g., the bar) appointing a majority. ${ }^{148}$

Redressing the past unresponsiveness to the poor may depend, as at the national level, on the ability and performance of the client community members of boards, not merely on their number. Several measures, among them the following, might be taken to aid these members: special preparation in briefings and written materials for board meetings; explanations of the background of issues, especially if they are legal issues; adjustment of roles and procedures of meetings to increase their participation, such as rotating the chairmanship; arranging the time of meetings so that they are convenient for the poor (e.g., at night, so that those who work can attend); and setting the place of meetings in a community center rather than in private law offices downtown, in order to minimize inhibiting factors and encourage spectator attendance.

148. Resolving the methods for selecting governing board members would be one of the most difficult and critical issues faced by the Corporation. Both the elective and appointive methods have drawbacks. In special elections, turn-outs are ustually abysmally low and there would be difficulty in determining procedures for nominating and casting ballots on a geographical or constituency-wide basis. Appointment would mean sclection by groups or organizations which might be unresponsive to the needs of the constituency they supposedly represent. Apportionment of selection power among different groups, with widely different degrees of responsiveness, would require great flexibility and discretion, almost certainly undercutting the program's accountability. In the past, elections have been extremely rare. A wide variety of groups have been given power of appointment, including social service agencies, public officials, community action ncigh. borhood councils, or community action boards. In any case, it would secm desirable to set certain minimum restrictions to prevent boards, for example, from becoming self-perpetuating, and to attempt to insure that all board members are selected in a way that makes them responsive to the constituency they are chosen to represent. 
The addition of a client's advisory council at the local level might be useful if it were given specific funds and responsibility to prepare periodic evaluations of the program. Such a council might also be given power to suggest revisions in the budget before it is submitted to the Corporation for funding; to veto particular hiring or firing decisions unless overridden by a majority of the governing board; to have unrestricted access to clients and attorneys in gathering information; and to prepare a "priorities report" outlining community problems in terms of both law reform and individual representation, discussing their relative importance. ${ }^{140} \mathrm{~A}$ number of observers have argued that without this "separatist" approach to representation of the poor client community members of governing boards will inevitably continue to be "overwhelmed," "inhibited," "subtly put down," if not "shut up" or shut out by other constituencies. 150

c. Division of Responsibilities. The Corporation must determine how responsibility is to be divided in two respects: (1) between the national board and the local governing boards and (2) between local governing boards and their staff attorneys. Division of responsibility in the first respect should depend to a large extent on how closely the allocation of control over each institution in fact conforms to the impact-contribution analysis presented above. If both the national board and local boards conform to this analysis, a substantial delegation of power would be desirable in order to allow flexibility in dealing with varying local conditions. The extent of the responsibility to be delegated should also depend on the issue to be decided, since constituencies have claims of varying degrees of legitimacy on different issues. For example, even if local boards remain under the excessive control of local bar associations, a substantial degree of delegation to

149. The establishment of a local clients advisory council need not prevent the gov. erning board from serving in accordance with the legislation as the primary "policy. making" body. The role of the council would be only consultative on most matters; the governing board would be obliged to grant the council a hearing, but not necessarily to follow its views. On other matters, however, the council might be given greater authority and its role might be collaborative. For example, the council might have the power to advise and consent to the hiring of specific staff members, subject to being overridden by a majority vote of the governing board. This might include the power to propose individuals for appointment by the board, in addition to assessing the board's nominees. A personnel decision has particular importance to clients because it is their only opportunity to decide in effect who will serve them as lawyers.

150. Interview with Hamilton, supra note 45. According to Aarjellen Hamilton, "poor folks just can't have much say on the boards." Likewise, Jean Cahn contends that there is little prospect of clients having a significant impact on the program through participation on such boards, because they are almost always "manipulated" or "outvoted." Interview with Cahn, supra note 45 . See also Pje \& Cochran, supra note 46, at 571 . 
them may be warranted on the issue of eligibility standards because of the impact this issue has on the professional community.

Insofar as responsiveness requires delegating authority, it may tend in practice to undercut policysetting and thereby open the program to political interference in some degree. If no delegation were permitted and all policy were set by the Corporation, the program might be almost totally insulated politically but seriously unresponsive to the needs and desires of constituencies at the local level as well. It often will be necessary to reconcile the requirements of responsiveness and policysetting. For each issue alternatives must be sought out which will minimize the tension between these two principles. ${ }^{161}$

With respect to the division of responsibilities between governing boards and staff attorneys, three major approaches have been suggested. One, recently proposed in an OEO draft guideline, would be to give governing boards a limited "oversight" function restricted to insuring compliance by the staff attorneys with Corporation policies. The local governing board would be precluded from infringing on the project director's authority to "conduct operations ... handle litigation or manage personnel."152 The American Bar Association has recommended a second approach which would give local boards a "general policymaking" function empowering them to "set broad guidelines respecting the categories or kinds of clients" and to act as a "managing or senior partner in a law firm," though abstaining from decisions case by case, client by client. ${ }^{153}$ As a third approach, the Corporation might give local boards a "case-by-case policymaking" function, allowing them to set broad guidelines and make specific decisions on types of clients or cases before they are accepted. The boards would also have greater control over the hiring and firing of staff as well as decisions on appeals and negotiations.

151. Theoretically, it might be argued, responsiveness should be fully compatible with policysetting. Where authority is delegated, it should still be possible to achicve all the elements of policysetting. See pp. 233.35 supra. The practical difficulty of doing so, however, is great. Almost inevitably, there will be some slippage-in articulation of policy, pinpointing of responsibility or enforcement-as discretion is opened down the line. The result may be some increased degree of vulnerability to political interference. Insofar as increased responsiveness results in the program dealing flexibly with the most urgent and genuine grievances of the client community, it raises the probability of op. position from those whose interests are thrcatened.

152. Draft, Guidelines for Governing Boards of Legal Services Programs (unsigncd and undated). Several drafts of these guidelines were written in 1970, and werc dis. seminated for comment, but were never issted. Interview with Speaker, supra note 14.

153. ABA Committee on Ethics and Professional Responsibility, Formal Opinion No. 324, Aug. 9, 1970. See generally ABA Canons of Professional Etilics No. 5, Etilicat. Considerations 5-1, 5-24, Disciplinary Rules 5-101, 5-107 (1970). 
Confining the governing board to "oversight" of the staff attorneys would seem to give the legal services lawyers more power over the program than the impact-contribution analysis conducted above would justify. ${ }^{154}$ Though the governing board might choose the project director, its policymaking powers would be emasculated. On the other hand, permitting a case-by-case, client-by-client, consideration of policy by the board would be more likely to open the governing board to political interference. ${ }^{155} \mathrm{~A}$ general policymaking function, as under the ABA's suggestion, would seem preferable because it combines a measure of responsiveness with the political insulation provided by prospective policysetting. ${ }^{156}$

\section{Eligibility}

The need for policysetting is especially acute in dealing with the issue of eligibility because under almost any proposed standard some degree of policymaking authority will be delegated to local governing boards in order to cope with diverse local needs. Responsibility for setting standards must be clearly delineated and the factors to be considered must be clearly set forth by the Corporation. The issue of eligibility also involves critical claims to responsiveness because of the tremendous impact of eligibility decisions on the client and professional communities. Depending on the eligibility standards adopted, large numbers of the poor may be excluded from service, or private attorneys may be damaged in their practice.

The issue of eligibility is normally understood to pertain only to financial factors. The Corporation must face two issues: first, which financial factors are to be considered and, second, whether and which non-financial factors should also be part of the eligibility standard. In the past, eligibility has been determined almost exclusively on the basis of income: an individual's take-home pay or other income is measured

154. See p. 271 supra.

155. See pp. 258-59 supra.

156. Any of these options might be implemented through the use of uniform con. tracts defining the relationship between the Corporation and governing boards, and between the governing boards and staff attorneys. The common thread running throughout the program's organization would then be one of contractual obligation. In the past, grantees had virtually no right to a hearing in the event the OLS denied refunding. Project attorneys were employees of their governing boards, but they frequently had no contracts. Their rights and obligations in relation to the board, and their relationship with clients, were undefined. A draft model contract was prepared recently by OLS officials, but was never disseminated for comment, or formally adopted. Establishment of contractual obligations would both assure elementary due process for projects and attorneys, and make clear the rights and responsibilities of the contracting parties at each level of the program. 
against a general income index of poverty. Standards based solely on income, however, ignore the factor of cost-particularly variations in cost for different kinds of legal services in different parts of the country. ${ }^{157}$ Financial factors other than income might be specified, such as savings or cash on hand, equity in property, ability to borrow from friends or relatives and debts or continuing payments or expected medical expenses. The standard might also consider the total costs of counsel: the probability of protracted litigation, the possibility of ap. peals, the necessity for expert witnesses or special studies or other unusual evidence and the chances of success and of attorney fees and court costs being charged to the opponent. Also, policy should be set in a number of related areas including the eligibility of the "voluntary" poor and the measure of "voluntariness," the eligibility of groups and the determination of the adequacy of the group's resources and the consideration to be given an individual whose case has been refused by a number of private attorneys.

Under a standard based solely on reasonable financial need, the program, operating with present or foreseeable levels of funding, could not possibly serve all individuals unable to afford private legal assistance. Among these individuals difficult eligibility choices will have to be made. Financial factors alone will not suffice as criteria. Nonfinancial factors to be considered might include the ability of the individual to obtain employment, marital status, whether the individual has previously been a client and, perhaps most important, the nature of the problem and the potential significance of the case both to the individual and to the client community. ${ }^{158}$

157. The income poverty index commonly used by projects was sharply criticizcd by the Senate Committee on Labor and Public Welfare: "testimony beforc the com. mittee has emphasized anew the arbitrary nature of the poverty index." SENATE RErORT, supra note 1, at 5-7. This index, as computed by the Social Security Administration, is presently set at $\$ 3,970$ for a family of four. Id. As Miss Mollie Orshansky of the Social Security Administration told the Committee, the basis of the poverty index is an assumption, derived from a 1960.61 survey conducted by the Labor Department and Agriculture Department, which "suggested that the food expenditures of average families of three or more represented about one-third of their money income after taxes." 1971 Senate Hearings, supra note 106, pt. 1, at 70. Although other agencies stich as the Bureau of Labor Statistics in the Labor Department have also designed indexes, the Social Security Administration index was made the official figure for use by Government agencies by direction of the Bureau of the Budget, in Budget Circular No. A.46, Trans. mittal Memorandum No. 9, Aug. 29, 1969. This index consists of the 1969 base year index adjusted annually only for price changes reflected in the Consumer Price Index, and with a smaller farm-non-farm differential. 1971 Senate Hearings, supra.

158. Although the legislation provides that the Corporation must give "priority" to individuals whose means are least adequate (The Bill $\S 1006(\mathrm{a})(8)$ ), the legislative history of the program strongly suggests that Congress contemplates including the "near poor" for service to some extent. The House Committee on Education and Labor said that 
Several policy options are available to the Corporation. First, it might set standards of financial eligibility at so low a level that no other policy would be necessary: with means standards set very low, the program would be able to serve all who qualified. Such a standard would fully define policy and avoid the need for articulating further responsibility at other levels in the program, but it would prevent projects from responding to diverse local conditions and from meeting the needs of those generally considered to be poor.

Second, the Corporation might set financial standards sufficiently high that not all legally eligible individuals could be served, but define no further criteria for decisions among such individuals. Governing boards would be required to establish such criteria but would have full discretion in doing so. Such a policy would augment responsiveness to local conditions but might undermine policysetting: the delegation of authority, even if pinpointed, would be extraordinarily broad. There would be substantial variation among programs on eligibility decisions. Moreover, the Corporation would have no criteria by which to evaluate such policysetting. Such a policy, in practice, might be indistinguishable from the one currently used-that is to say, no policy at all.

As a third option, favored here, the Corporation might set financial factors as outer limits, but mandate the criteria to be applied, in some order of importance, in deciding who would be served first among those who qualify. Local governing boards would have discretion within limits circumscribed by such criteria. Financial factors to be considered might include those contained in the Administration's original bill, i.e., the assets and income level of the client; the fixed debts, medical expenses and other factors which affect the client's ability to pay; the size of the client's family; the cost of living in the particular locality; and other factors related to financial inability to afford legal counsel. ${ }^{159}$ Those least able to afford private counsel might be given prefer-

it was "interested in the possibility of legal services being extended to the so.called "near poor" " and mandated the Corporation to study "how best this can be accom. plished." HOUSE REPORT, supra note 1, at 33. The Senate Committee on Labor and Public Welfare recommended that the legislation authorize the program to acecpt such clients and charge them. SENATE REPORT, supra note 1 , at 36.

159. H.R. 8163, 92d Cong., Ist Sess. \$ 905(a)(2) (1971) and S. 1769, 92d Cong., lst Sess. $\$ 905(\mathrm{a})(2)$. These provisions viere not included in the legislation approved by Congress. S. 2007, which the President vetoed. The Administration's bill contained a number of other important provisions rejected by Congress, as a result of opposition from the bi-partisan coalition of legal services supporters, and thus differed significantly from the final version passed. It would have provided, for example, for (i) negotiation by the Corporation on behalf of clients with federal agencies in order 10 aroid litigation 
ence. But non-financial factors should also be considered, such as the significance of the case to the local community or a specified number of rejections of the case by private attorneys. This third option would seem preferable, since it would both satisfy the requirements of policysetting and allow substantial flexibility for responsiveness to constituencies at the local level.

\section{Services}

The issue of services, as indicated above, ${ }^{100}$ presents the Corporation with essentially two questions: what distinction is to be drawn between permissible and impermissible services, and what priorities will be established among permissible services? Answering the first question amounts to setting the outer boundaries of legitimate activity for legal services attorneys, which is comparable to defining financial parameters for eligibility. Though the proposed legislation would incorporate the two major existing restrictions, relating to criminal representation and lobbying, the Corporation would presumably have authority to adopt others if a sufficient need arose.

Answering the second question involves applying criteria of preference or need to establish a ranking among the types of permissible services. Since the proposed statute would not specify the categories of services to be ranked, or even the level where the decision should be made, the Corporation would have broad discretion to do so. The scarcity of the program's resources makes the decision particularly im. portant, since only a few of the potential priorities may be served.

In determining the extent of authority to be delegated to governing boards on these two questions, the Corporation has available a number of possible approaches. One would be to retain total power over policy with respect to both questions, setting detailed guidelines on imper* missible activities and strict requirements for allocation of attorney time. A second approach would be to delegate maximum authority to the local governing boards on both questions, merely repenting the legislative language regarding permissible activities, while setting no requirements whatever on priorities. As a third approach, the Corporation might leave maximum discretion to the governing boards on per-

(\$ 904(b)(3)) (ii) establishment of guidelines for a system of review of appeals in indi. vidual cases $(\$ 905(\mathrm{a})(8)$ ) and (iii) a prohibition on any grants or contracts with "public interest law firms" (\$ $905(\mathrm{~b})(3))$.

160. See pp. 253-56 supra. 
missible activities but set detailed requirements as to the use of the projects' resources and attorney time. Finally, the Corporation might set detailed guidelines on impermissible activities and define certain categories of permissible services, but leave substantial discretion to local governing boards to decide priorities among these categories.

A strong argument may be made for the Corporation setting policy on permissible types of services, as under the first and fourth approaches, on the grounds that the reasons for judging one type of activity permissible and another impermissible should apply to all programs. Such reasons might be, for example, the unethical nature of certain services, the extravagant expense involved, or congressional intent. It can be argued equally strongly that substantial authority on priorities should be delegated in order to allow for maximum responsiveness to the particular problems of clients and local conditions. The fourth approach thus seems preferable to the first, because it would delegate discretion for setting priorities among clearly defined categories of service within parameters of permissibility set by the Corporation.

\section{Other Aspects of Policysetting}

In dealing with issues of eligibility and services, the Corporation would be well-advised to build effective mechanisms for reviewing all decisions of local governing boards and evaluating them in terms of established policies. Astonishingly, no such mechanism has existed in the history of legal services. Procedures should be established, as a number of observers have suggested, for review and approval of guidelines established by local boards. ${ }^{101}$ These procedures, along with the standards set by the national Corporation, should be published officially in the Federal Register and the Code of Federal Regulations. In addition, there might be procedures for periodic spot checking by the Corporation to insure that the policies established by the local board and the Corporation are being followed. Reporting requirements with respect to specific forms of data, including client "profiles" in terms

161. See Curtis E. von Kann \& Gary Fontana, A Model Brief for the Proposition that A Trial Judge Has No Power to Conduct A Collateral Inquiry Into A Civil Litigant's Eligibility for Representation by A Legal Services Attorney, Aug. 13, 1971. See also Letter from Curtis von Kann, attorney, to Jason Newman, Special Counsel to the Director of OLS, Sept. 3, 1971. The Management Information System (MIS), the OLS' main device for obtaining data from projects on a regular basis, provides only very limited types of information; many projects have failed to file AIS reports, and relatively rarely has OLS demanded them. 
of eligibility factors, should be a part of the application and funding process. The evaluation system should be greatly strengthened to pro. vide for periodic assessments of project performance by the staff and board of the project as well as by outside teams. Visits by outside teams should be arranged for adequate periods of time, and the teams should include individuals capable of providing advice and technical assistance to the project. Data should be compiled uniformly for the program as a whole so that long range trends can be identified. Finally, the Corporation might also consider establishing administrative mechanisms to consider complaints about local project decisions with respect to eligibility, services or any other issue. Such a mechanism might pro. vide, for example, quick review of complaints by a party opponent or another person aggrieved by a local board decision to provide, or refuse, representation to a particular individual.

\section{Conclusion}

A need for more adequate policysetting and responsiveness has been frequently expressed by clients, legal services attorneys and government officials. The time to fulfill that need is now, since the program will probably be governed soon by a new, independent structure. The legal services program has earned a measure of public acceptance and even enthusiasm. Even now, however, it is not free of the threat of political interference. This threat can be expected to grow as the program gains in power and fulfills its immense potential. As a Corporation no less than a branch of the government, legal services is entering a new time of testing. 